Gerando possibilidades concretas de uso da Proposta Curricular do Estado com Metodologias Investigativas 
SERVIÇO DE PÓS-GRADUAÇÃO DO ICMC-USP

Data de Depósito:

Assinatura:

\title{
Gerando possibilidades concretas de uso da Proposta Curricular do Estado com metodologias investigativas
}

\author{
Cláudia Flora Degrava
}

Orientadora: Prof. ${ }^{\text {a }}$ Dra. Edna Maura Zuffi

Dissertação apresentada ao Instituto de Ciências Matemáticas e de Computação - ICMC-USP, como parte dos requisitos para obtenção do título de Mestre em Ciências - Programa de Mestrado Profissional em Matemática. VERSÃO REVISADA

\section{USP - São Carlos}

Abril de 2013 
Ficha catalográfica elaborada pela Biblioteca Prof. Achille Bassi e Seção Técnica de Informática, ICMC/USP, com os dados fornecidos pelo(a) autor(a)

Degrava, Cláudia Flora

D321g Gerando possibilidades concretas de uso da Proposta Curricular do Estado com metodologias investigativas / Cláudia Flora Degrava; orientadora Edna Maura Zuffi. -- São Carlos, 2013.

$67 \mathrm{p}$.

Dissertação (Mestrado - Programa de Pós-Graduação em Mestrado Profissional em Matemática em Rede Nacional (PROFMAT)) -- Instituto de Ciências Matemáticas e de Computação, Universidade de São Paulo, 2013.

1. Metodologia Investigativa. I. Zuffi, Edna Maura, orient. II. Título. 
"Apesar dos nossos defeitos, precisamos enxergar que somos pérolas únicas no teatro da vida e entender que não existem pessoas de sucesso e pessoas fracassadas. $O$ que existem são pessoas que lutam pelos seus sonhos ou desistem deles."

(Augusto Cury) 



\section{Agradecimentos}

Dois anos se passaram. Ou melhor, voaram. Chegou a hora de parar e agradecer.

Primeiramente agradeço a Deus, pela minha vida, pela saúde de meus familiares. Dificuldades são muitas. Maior ainda foi a força de vontade. Indo e vindo, sempre por Ele acompanhada.

Agradeço e dedico este trabalho ao meu esposo, a quem peço desculpas pela minha ausência nesses anos. Com toda paciência, carinho e companheirismo, sempre esteve ao meu lado.

Agradeço também aos meus filhos, Guilherme, Gabriela e Giovana, por estarem sempre grudados à mãe, e mesmo na minha ausência souberam crescer positivamente.

Agradeço ao meu pai, Delvo, e minha mãe, Ana, que me ensinaram a lutar e que “trabalhar não mata ninguém”. E também as minhas irmãs, avó Deolinda, meus tios, minhas tias, em especial tia Neusa e tia Dalva, que são modelos de ser humano, pelas quais sempre tive grande admiração. Ao Lucas, meu muito obrigado, por ser exemplo de determinação e ensinar a todos que, através de nossas lutas sempre alcançaremos nossos objetivos.

Não podia deixar de agradecer ao Marcão e à Regina, ao Marcos e a Fabiana, pela paciência que tiveram em ouvir meu desespero, toda vez que retornava de São Carlos, proporcionando momentos agradáveis, com cerveja, churrasco, risadas e muito mais.

Obrigado Wilma, pela educação dos meus filhos, e por ter cuidado tão bem da minha casa e da minha família nesses anos.

Não posso esquecer-me dos colegas de trabalho que, incansavelmente me viram estudar, e sempre se preocupavam, encorajando-me e apostando nas minhas conquistas. Agradeço a todos, principalmente àqueles que estiveram mais presentes como o Fernando, Maíra, Andréia, Rodrigo, Patrícia, Mariana, Marcia, Munira, Sônia e Neiza.

Agradeço aos amigos, presenteados com este curso, em especial à Daniela e sua família, por terem me acolhido em sua casa, me auxiliando nos momentos mais difíceis, com toda sabedoria e integridade. 
Não posso esquecer jamais de meus professores, mestres, sem os quais eu jamais estaria aqui. Na primeira série, Dona Célia Bertoldo, magnífica. Minha primeira e inesquecível professora de matemática: Zezé Nassur, onde minha paixão pela disciplina floresceu aí, como uma dádiva das salas de aula. Ao Juarez, na graduação, muita admiração pelo seu trabalho. Agradeço a todos os professores do ICMC, à minha orientadora Edna, pela paciência, determinação e exemplo de profissionalismo. E não poderia esquecer professora Ires. Não tenho palavras para agradecê-la pela oportunidade, pela insistência, pelas palavras de conforto, sua amizade e seus ensinamentos. Que Deus continue a abençoá-la por muitos e muitos anos de sua vida.

Pela oportunidade única, agradeço a SBM pela criação do Profmat, a CAPES pelas bolsas concedidas e à USP pela participação no programa.

E como disse Ayrton Senna: "Se você quer ser bem sucedido, precisa ter dedicação total, buscar seu último limite e dar o melhor de si." Assim foi e sempre será. Muito obrigada! 


\section{Resumo}

Um dos maiores desafios da educação, em especial da Matemática, é fazer com que o aluno, ao produzir conhecimentos, o faça de forma significativa. É nesse sentido que, esta dissertação busca mostrar, através de uma pesquisa-ação, como atividades investigativas abrem caminhos para a busca de conhecimentos de forma crítica e reflexiva, além de possibilitar o desenvolvimento pessoal e ser capaz de integrar conteúdos das disciplinas com o cotidiano do educando. A aplicação desta metodologia para alunos do sétimo ano de uma escola pública mostrou que a parceria entre professor e alunos edifica e fortalece esta construção dos saberes e que a existência de um contrato didático negociado foi fundamental nesse processo.

Palavras-chave: Atividades investigativas, contrato didático, pesquisa-ação. 



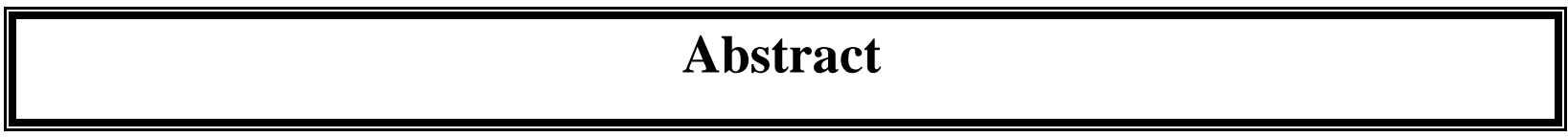

One of the biggest challenges in education, especially in mathematics, is to provide students the production of significant knowledge. In that sense, this paper seeks to show, with a qualitative action-research, how investigative activities open paths to the search for knowledge in a critical and reflective way, to enable personal development, and integrate content from disciplines with the students' everyday experiences. The application of this methodology to seventh grade students in a public school showed that the partnership between teacher and pupils builds and strengthens this construction of knowledge, and that the existence of a negotiated didactic contract was essential to this process.

Keywords: Investigative activities, didactic contract, qualitative action-research. 



\section{Lista de Ilustrações}

Fig. 1 - Questões Diagnósticas.............................................................................. 35

Fig. 2 - Cabeçalho da Proposta aos Alunos ............................................................... 37

Fig. 3 - Contrato Didático Negociado ............................................................................ 44

Fig. 4 - Momento da Coleta de Dados ......................................................................... 48

Fig. 5 - Registro da coleta de dados, pelo grupo 2, sobre a matéria preferida na escola ...... 49

Fig. 6 - Continuação dos Registros do grupo 2, com observações adicionais ................... 50

Fig. 7 - Registro da coleta de dados, pelo grupo 3, sobre o comportamento dos alunos...... 51

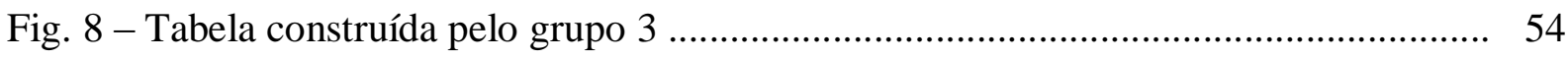

Fig. 9 - Cálculo para a construção do gráfico, pelo grupo 3 …....................................... 55

Fig. 10 - Gráfico de setores "Como é o seu comportamento em sala de aula", grupo 3...... 56

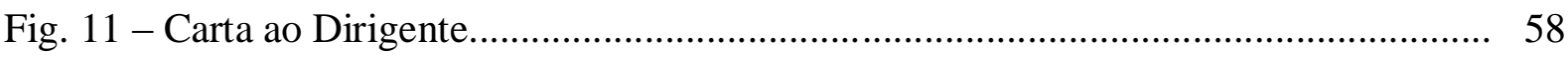





\section{Lista de Tabelas}

Tab.1 - Critérios para avaliação do relatório

Tab.2 - Assuntos decididos para comporem o levantamento de dados. 46

Tab. 3 - Assuntos a serem abordados com cada grupo 47

Tab.4 - Estratégias adotadas por cada grupo, para cálculo de porcentagem. 53 



\section{Sumário}

Introdução.

1 Escolhas Metodológicas e os Sujeitos da Investigação

1.1. A Pesquisa Qualitativa

1.2. Tipos de Pesquisa Qualitativa

1.2.1 Pesquisa do tipo etnográfico

1.2.2 Estudo de caso

1.2.3 Pesquisa-ação

1.3. O Trabalho em Questão e os Sujeitos Investigados

2 Atividades Investigativas para o Ensino de Matemática

2.1. Significando as Palavras Investigar e Aprender .

2.2. Investigar em Matemática 28

2.3. O Benefício da Investigação na Prática Profissional do Professor

3 A Proposição de uma Seqüência Didática e sua Aplicação

3.1. Atividade "Mostrando a Nossa Cara" 36

3.1.1 Primeira etapa (ou tarefa) 36

3.1.2 Segunda etapa (ou tarefa) 39

3.1.3 Terceira etapa (ou tarefa) 39

3.1.4 Quarta etapa (ou tarefa) 40

3.1.5 Quinta etapa (ou tarefa) 40 
4.1. O Desenvolvimento dos Alunos com a Atividade Investigativa

4.1.1 O início de tudo ........................................................................ 43

4.1.2 Quais informações coletar? ........................................................ 46

4.1.3 Coletando e organizando os dados ............................................... 47

4.1.4 Aprendizagens sobre porcentagem, tabelas e gráficos .................. 52

4.1.5 Melhorias com a expressão oral e escrita .................................. 57

4.1.6 Melhoria no relacionamento interpessoal dos alunos .................... 59

4.1.7 Como ficou a relação professora-alunos ..................................... 59

4.2. Formação Profissional Docente ......................................................... 60

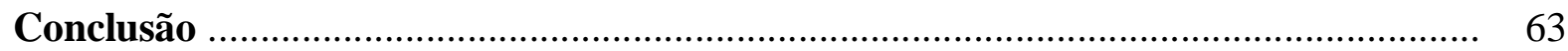

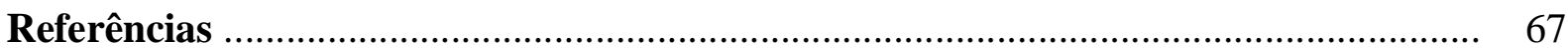




\section{Introdução}

Mediante o desafio de dar aulas para uma turma indisciplinada e pouco participativa, a professora-pesquisadora buscou novas estratégias e metodologias de ensino. Foi aí que ocorreu o aprimoramento, com leituras e reflexões, sobre atividades investigativas.

Nesse sentido se fez importante esta pesquisa-ação que busca integrar os avanços matemáticos, obtidos no decorrer do curso, com uma possibilidade de melhoria em sala de aula.

Como projeto inicial, a professora se identificou com o objetivo da proposta "Necessidade de integrar a Proposta Curricular do Estado com atividades investigativas em Matemáticas"- e foi instigada por uma tarefa: aplicação em uma sala de aula desafiadora.

Seria possível a realização de uma tarefa investigativa, em matemática, em uma sala de aula com características de indisciplina e pouco participativa? Como seria o aproveitamento, quanto aos conteúdos matemáticos e ao desenvolvimento das relações interpessoais, em sala de aula?

Esses questionamentos nos levaram às leituras e à construção da pesquisa.

No capítulo 1, será abordada a questão das pesquisas qualitativas. Com essa leitura, pode-se perceber que este trabalho caracteriza-se como um estudo de caso e uma pesquisaação. Além desses tipos de investigação, também serão caracterizados a pesquisa do tipo etnográfico e pesquisas qualitativas, em geral. Ainda neste capítulo, serão apresentados os sujeitos desta investigação e o ambiente escolar que frequentavam, a fim de evidenciar os motivos pelos quais foram escolhidos.

No capítulo 2, será apresentada a metodologia de ensino com atividades investigativas, de uma forma ampla e consistente, mostrando a importância do investigar e sua relação com o aprender. Para melhor posicionar as atividades investigativas, será feita uma comparação entre os tradicionais exercícios, os problemas, as explorações e as investigações.

A sequência didática aplicada aos alunos será apresentada no capítulo 3 e seus resultados, analisados no capítulo 4. Mediante uma avaliação diagnóstica, fez-se necessária a 
construção dessa sequência, que buscasse desenvolver tanto a aprendizagem, quanto o posicionamento dos alunos no meio. Intitulada como "Mostrando a Nossa Cara", ela visa às investigações na matemática, mas além de tudo, busca integrar os indivíduos como corresponsáveis pela aprendizagem e reflexivos quanto ao seu posicionamento na sociedade.

Finaliza-se o trabalho com reflexões relacionadas à formação profissional da professora-pesquisadora, mostrando os resultados deste trabalho e suas conquistas, em especial quanto ao desenvolvimento do conhecimento pedagógico do conteúdo. 


\section{Capítulo 1}

\section{Escolhas Metodológicas e os Sujeitos da Investigação}

O presente trabalho tem como característica principal uma abordagem qualitativa. Mas afinal, como saber se um trabalho é ou não qualitativo? Apenas por não apresentar dados numéricos (quantidades)? Mas se forem quantificadas algumas informações, deixaria de ser qualitativo?

Este capítulo tem por objetivo delinear as escolhas metodológicas para esse trabalho, bem como caracterizar os sujeitos envolvidos nesta pesquisa.

\subsection{A Pesquisa Qualitativa}

Não se pode perder de vista que quantidade e qualidade estão intimamente relacionadas. Pode-se, por exemplo, fazer um estudo da aprendizagem dos alunos e apresentar a análise final em números. Vejamos o Relatório Pedagógico do Saresp-2011 - $7^{\circ}$ ano do Ensino Fundamental em Matemática: 38\% dos alunos da rede pública de ensino do Estado de São Paulo sabem resolver problemas sobre Grandezas e Medidas. Imagine-se, no lugar de dados numéricos, existirem apenas o registro de que alguns alunos sabem resolver tal situação. Percebe-se que, mesmo usando números, por trás existe uma análise teórica e uma visão do todo abordada por detalhes que tornam o trabalho, de certo modo, qualitativo.

Outro exemplo importante pode ser notado no resultado de avalições onde o professor tem a necessidade de quantificar a aprendizagem. Mas nem por isso o processo deixa de ser qualitativo. Em cada interferência, em cada questionamento e/ou reflexão, existe uma significância, existe um processo formativo que torna a atividade qualitativa.

Porém, é em um sentido mais profundo que se caracteriza a "pesquisa qualitativa", neste trabalho, como se propõe a seguir. 


\subsection{Tipos de Pesquisas Qualitativas}

\subsubsection{Pesquisa do tipo etnográfico}

Esta abordagem foi desenvolvida por antropólogos para estudar a cultura e a sociedade (práticas, hábitos, crenças, valores de uma determinada comunidade), e tem sido usada pelos estudiosos da educação para entender o processo educativo.

Devido ao fato do pesquisador interagir com a situação estudada e ser afetado por ela, esse tipo de pesquisa é caracterizado pela observação participante. Com a intenção de esclarecer problemas observados, faz-se também uso de descrições de entrevistas, e para completar e aprofundar as informações coletadas pode ser realizado análises de documentos. Com todos esses detalhes atendidos, a pesquisa usada por educadores se assemelha à prática dos antropólogos.

Outra característica importante dos estudos qualitativos é a ênfase no processo, naquilo que está ocorrendo, e não somente em seu produto ou resultado final. Existe uma preocupação com o significado, com a forma de como as pessoas veem a si mesmas, suas experiências e o mundo que as cerca. Nesse tipo de pesquisa, o instrumento humano é fundamental para a coleta e análise dos dados. O papel do pesquisador é apreender e retratar a visão pessoal dos participantes. Para isso, faz uso de palavras ou textos e descreve situações, pessoas, ambientes, depoimentos ou diálogos.

Em geral, também inclui o trabalho de campo, onde o pesquisador se aproxima das pessoas, situações ou locais a serem estudados, mantendo um longo contato. Influenciará muito nesta etapa o tempo disponível, a aceitação do grupo, experiências já vivenciadas e o número de pessoas envolvidas.

Como relata André (1995), a pesquisa etnográfica não tem como objetivo principal testar hipóteses pré-estabelecidas. Ela busca formulá-las no processo investigativo, propondo, ainda, conceitos, abstrações ou teorias. Para isso é necessário um planejamento flexível para que as reformulações vão sendo realizadas ao longo do processo. Ela visa criar novos conceitos ou novas formas de entender a realidade. 


\subsubsection{Estudo de caso}

No dia-a-dia de alguns pesquisadores, vários estudos de caso são realizados, como na medicina, em empresas ou no campo jurídico. Na educação, o estudo de uma escola, de um professor, de um aluno ou sala de aula também é considerado estudo de caso. Este tipo de pesquisa é importante para a compreensão de situações especiais que podem ocorrer no ambiente pesquisado.

Para ser considerado um estudo de caso etnográfico, deve preencher os requisitos da etnografia e deve ser bem delimitado, com a escolha, bem justificada, de uma pessoa ou uma sala de aula, por exemplo. A partir de um plano de trabalho flexível, escolhe-se uma unidade a ser estudada e busca-se a formulação de novos conceitos e novas abordagens, a partir do caso investigado. Nesse trabalho, a avaliação e reavaliação devem ser constantes e tem como principal função a tomada de decisão para a reformulação das técnicas de coleta e fundamentos teóricos.

\subsubsection{Pesquisa-ação}

Este tipo de investigação qualitativa baseia-se primeiramente na análise, coleta de dados e conceituação dos problemas a serem pesquisados. Em seguida, demanda um planejamento da ação, sua execução e uma nova coleta de dados. E o ciclo de análise deve ser repetido, com a proposta de novas ações, se for o caso.

Um exemplo prático da pesquisa-ação no ambiente escolar é o professor que busca alterar o nível de aprendizagem de sua sala, e para isso, faz uso de nova metodologia. Faz uma análise prévia para diagnosticar, e com um processo de intervenção planejada, vai coletando dados, analisando, relatando e refazendo todo o processo.

Esse tipo de pesquisa pode seguir várias linhas, tendo entre elas um caráter diagnóstico, uma preocupação com o currículo, ou podendo, ainda, ser voltada para o desenvolvimento profissional do professor. Pode ser muito apropriada para discutir a formação continuada de professores e a educação de adultos.

Dentro dessa vertente, desenvolveu-se uma linha denominada "pesquisa participante ou participativa”. Nesta, há um envolvimento dos participantes e a necessidade de uma devolutiva sistemática para resultar numa melhoria para um grupo. Existe ainda, a corrente 
pesquisa-ação institucional, com o objetivo de tornar as ralações sociais mais justas numa dada instituição, e a corrente investigação colaborativa, em que predomina o trabalho coletivo e a colaboração intensa entre todos os envolvidos.

Em resumo, todas essas vertentes da pesquisa-ação tem um plano de ação bem delineado, baseado em objetivos que se pretende alcançar e um processo de acompanhamento e controle da ação, além de relatos constantes.

\subsection{O Trabalho em Questão e os Sujeitos Investigados}

Esta investigação se caracteriza como uma pesquisa-ação, em que a partir de um diagnóstico de uma sala de aula e de uma preocupação com o currículo adequado para atender as suas necessidades, a professora-pesquisadora buscou alterar o nível de aprendizagem de seus alunos, fazendo uso de uma nova metodologia. A partir da coleta de dados da aplicação proposta e executada pela professora, faz-se a análise dos processos envolvidos, tanto para a aprendizagem matemática de seus alunos, quanto para o seu próprio desenvolvimento profissional com essa experiência.

Os sujeitos investigados correspondem a uma turma de sétimo ano de uma escola estadual, da cidade de São João da Boa Vista, interior de São Paulo, em que esta professorapesquisadora atua como docente, desde o início do ano de 2012.

Atualmente essa escola mantém o ensino fundamental e o $1^{\circ}$ ano do ensino médio, sendo formada por onze classes do primeiro nível, com um total de 313 alunos, e duas classes do segundo, com um total de 77 alunos. O funcionamento se dá nos períodos da manhã e tarde. A maior parte dos alunos são moradores de um bairro carente, que enfrenta muitos problemas de violência e drogas, problemas estes que se refletem no comportamento de muitos alunos, desde o linguajar até atitudes violentas. Neste sentido, a escola carrega sérios desafios e enfrenta preconceitos relacionados aos alunos e aos bairros que atende. Além desses, atende também alunos de zona rural, que corresponde a $21 \%$ do total. Ainda por conta da localização ou condição financeira, há muita dificuldade em se trabalhar com pesquisas dos estudantes sobre os conteúdos escolares, uma vez que muitos não têm acesso à internet em casa e usá-la apenas no laboratório de informática da escola não é suficiente. 
Quanto ao espaço físico, apresenta onze salas de aula, mais uma de recurso e uma de informática, sendo dez na parte superior e três na parte inferior. As salas de aula e os demais ambientes da escola estão relativamente conservados, considerando que foram pintadas há pouco tempo. A maior parte das carteiras é frequentemente rabiscada pelos alunos e, portanto, não são bem conservadas. Todas as salas possuem um ventilador e amplas janelas, com cortinas, deixando o ambiente mais arejado; são bem iluminadas e seu espaço atende adequadamente ao número de alunos. Além das cortinas, as janelas da escola contêm grades, o que pode dizer muito sobre o lugar. Estas cumprem papéis variados, tanto para evitar a entrada e saída de pessoas, quanto de objetos e drogas. Assim, as grades nas janelas são elementos recentes e necessários para a segurança do ambiente.

Em relação aos recursos didáticos, apenas duas salas de aulas contém lousa branca que faz uso de pincel atômico; as demais têm lousa convencional e todas possuem mais uma lousa na parede lateral, que não é usada. No pavimento superior, todas as salas possuem TV e o único aparelho de DVD deve ser agendado pelos professores. Também possui um retroprojetor, montado na sala de informática, que contém 10 computadores para uso dos alunos e um notebook conectado ao retroprojetor. Os professores reclamam que há uma dificuldade de se trabalhar vídeos e aulas diferenciadas neste ambiente, pois muitas vezes o notebook não abre os documentos ou está em manutenção. Além dos computadores da sala de informática, a escola possui dois deles na secretaria, um na direção, um na sala dos professores, outro na sala da coordenação e um na sala de recursos. Os professores também podem usar tela de transparência, máquina fotográfica, amplificador e microfone, porém estes aparelhos são usados, na maioria das vezes, em eventos da escola, e não rotineiramente.

A escola também possui uma biblioteca pequena, mas bem montada, com muitas coleções de livros, revistas e vídeos para uso de alunos e professores. Ela, porém, é pouco usada; os alunos não se interessam muito e os professores não têm o costume de levá-los até lá. Todos os anos chegam ótimos materiais, incluindo vários filmes e coletâneas, porém ela não fica aberta e é necessário que um professor se responsabilize pelas chaves e o empréstimo de materiais.

A escola possui uma quadra de esportes coberta, no pavimento inferior, e um espaço descoberto também usado para educação física e jogos de campeonatos internos. Ainda, no pavimento inferior há uma cozinha e uma cantina, as quais os alunos usam como espaço de socialização durante o intervalo, além da quadra e do pátio descoberto. 
O planejamento escolar, que ocorre no início de cada ano, prevê avaliações diagnósticas e contínuas, que busquem responder se os objetivos foram desenvolvidos nos alunos. Além das avalições diagnósticas, os alunos participam de avaliações externas, como o SARESP, em nível estadual, e a Prova Brasil, em nível nacional.

Além do trabalho regular, a escola oferece, aos finais de semana, a "Escola da Família", que dispõe aos alunos e à comunidade, atividades diferenciadas e eventos comemorativos, levando sempre mensagens positivas, através de um trabalho sério e dedicado. A "Escola da Família" tenta se aproximar dos alunos e passar-lhes valores essenciais, mas que muita vezes são esquecidos no dia-a-dia.

A equipe gestora apoia os docentes na realização das atividades, embora, muitas vezes, não haja entrosamento e entendimento suficiente no processo de ensino e aprendizagem, problema este que acomete grande parte dos profissionais envolvidos no âmbito da educação pública do Estado.

A escolha da classe e dos alunos envolvidos neste trabalho se deu perante algumas características apresentadas no decorrer das aulas do $7^{\circ}$ ano do Ensino Fundamental, sendo elas de caráter educacional e comportamental. No total são 34 estudantes, sendo 18 meninos e 16 meninas. A média de idade é 12 anos e cerca de um terço deles são moradores de área rural. No geral, são alunos indisciplinados. O grupo iniciou o ano letivo com pouca, ou quase nenhuma, noção de posicionamento perante a aula: por exemplo, os alunos não traziam materiais escolares, não abriam seus cadernos, demoravam a se engajar nas atividades. Hoje, após vários meses de convívio, já conseguem se organizar melhor e participar da rotina diária. Porém, antes da realização desta pesquisa, a concentração ainda deixava a desejar, para a maioria deles.

Dois motivos que chamaram a atenção no grupo, os quais fizeram escolhê-lo para a atividade investigativa, foram: a aprendizagem e sua visão de mundo. Mesmo com toda a indisciplina e falta de controle, os alunos demonstravam uma vontade muito grande de aprender, e quando se mobilizavam, apresentavam rendimento satisfatório nas atividades propostas, tornando-se ativos e participativos. Ainda assim, eles apresentavam uma defasagem de conhecimentos, principalmente na língua materna, o que gerava também dificuldades quanto à aprendizagem em matemática. 
Em relação ao segundo motivo, em algumas rodas de conversa dentro da sala de aula, causaram espanto nesta professora com a incompreensão que possuem em relação ao sistema monetário. Além disso, demonstram claramente que "não têm medo do mundo". Disseram abertamente do desejo de se relacionarem, terem filhos e que viverão bem com apenas alguns reais. Isto motivou a pesquisa e a escolhê-los, a fim de propor atividades que os ajudassem a desenvolver o raciocínio crítico, levando-os a levantar hipóteses e argumentos para justificar suas escolhas, através de uma metodologia nova para eles, qual seja, o uso de atividades exploratórias e investigativas na aula de matemática. 


\section{Capítulo 2}

\section{Atividades Investigativas para o Ensino de Matemática}

Este capítulo tem como objetivo caracterizar e exemplificar a metodologia investigativa nas aulas de matemática.

Para o ensino de matemática, podemos considerar duas abordagens: a euclidiana, com teoremas, axiomas e ênfase no formalismo lógico-dedutivo, e a experimental-investigativa, com foco na construção de significados para as propriedades e os conceitos matemáticos investigados. Trataremos, neste texto, desta segunda abordagem.

\subsection{Significando as Palavras "Investigar" e "Aprender"}

Tradicionalmente, ensino e investigação são considerados atividades diferentes. O investigador descobre, inventa. O professor ensina. Porém, segundo Ponte (2003), na realidade, quem investiga procura aprender e quem aprende, em geral, passa a ter mais interesse em investigar.

Esta última palavra tem diversos significados atribuídos e alguns mitos relacionados. Alguns podem dizer que investigar envolve o uso de metodologias sofisticadas e que é papel de investigadores profissionais. As grandes investigações estão presentes em universidades, empresas, laboratórios e têm uma função social. No entanto, os autores aqui citados afirmam que investigar é procurar conhecer, solucionar e as investigações estão presentes em toda parte, em muitas atividades humanas, não necessariamente ligadas a pesquisas científicas e acadêmicas.

Aprender, assim como investigar, também é uma palavra que apresenta diferentes significados. No passado, esse termo poderia ser concebido como receber, reproduzir ou adquirir conhecimentos. Entende-se hoje que aprender é um processo natural e faz parte do ser humano desde os primeiros anos de vida. A fala é um exemplo de aprendizagem. E 
aprender matemática deve ser visto como um desenvolvimento harmonioso e integrado de competências e habilidades, envolvendo situações, processos, raciocínios e uso destes em situações reais, problemas reais e com uma postura crítica e reflexiva.

Do mesmo modo, podemos questionar: ser professor significa debitar matéria, usar lousa, projetor, transmitir informação? Ou ser professor significa promover a aprendizagem e avaliar resultados?

\subsection{Investigar em Matemática}

Dentro de uma abordagem mais ampla para estes termos, os autores Ponte et al (2003), consideram importante aproximar os alunos das tarefas exploratórias e investigativas.

A tarefa investigativa deve ter certo grau de dificuldade, uma estrutura que permita ao aluno questionar uma determinada situação que envolva raciocínios matemáticos, deve estar dentro de um contexto e ter um tempo adequado para sua resolução. Os acontecimentos, nessas tarefas, podem ser inesperados para o professor. Sempre têm um começo, mas nunca se sabe exatamente como será o fim, dependendo de como caminham as indagações dos alunos. O professor inicialmente prevê um tempo para sua execução, porém deve ter flexibilidade para dar novos encaminhamentos, em função das questões e hipóteses que possam vir a ser levantadas nesse processo. O melhor indicador é o próprio aluno, o qual pode mostrar sinais de cansaço ou de desejo de continuar.

Em relação ao grau de dificuldade e estrutura, Ponte (2003) classifica as tarefas dadas aos estudantes como:

- os tradicionais exercícios: estes não têm grandes dificuldades e apresentam uma estrutura fechada com enunciados sintéticos que levam a aplicação de cálculos e algoritmos.

- os problemas: apresentam um enunciado com palavras de língua materna e situações em que há uma certa dificuldades para resolução, não fornecendo o caminhado imediato para a solução. O aluno deve usar diversos conhecimentos prévios e associálos para chegar à solução, porém o professor já conhece o caminho e o resultado a ser alcançado pelo aluno, nesse caso. 
- as atividades exploratórias: também são abertas, porém com grau de dificuldade menor; são um pouco mais diretivas que as investigações. O mais importante numa atividade exploratória é a discussão final. Aquilo que parece evidente, muitas vezes não é verdadeiro e isso poderá ser constatado numa tarefa exploratória.

- as investigações: assim como os problemas, apresentam certo grau de dificuldade para os alunos, porém são mais abertas. As questões são desenvolvidas e os resultados serão percebidos no decorrer do processo. Resume-se a três momentos: propor a tarefa, investigar e discutir os resultados. Aquelas que apresentam um tempo maior para solução são denominadas projetos. Em relação ao contexto, as tarefas exploratórias e investigativas podem referir-se a uma situação real, puramente matemática ou semirreal (quando se refere a um contexto hipotético ou simplificado). Nessas atividades o professor não responderá as perguntas propostas, mas dará atenção, encorajará, atendendo as dúvidas dos alunos para formularem questões e para as argumentações.

A atividade investigativa, na maioria das vezes, parte de uma situação ou um problema que pode permitir uma, nenhuma ou várias soluções. Ela segue a seguinte divisão:

- reconhecimento e exploração da situação;

- preparação das questões;

- levantamento das hipóteses e conjecturas;

- recolhimento e tratamento dos dados;

- teste dos resultados;

- elaboração de relatório.

É necessária muita organização do professor e dos alunos para o desenvolvimento das tarefas investigativas. A postura mediadora do professor é o principal. Sua fase inicial é de fundamental importância. Ele deve garantir que o aluno entenda o sentido da tarefa. Isso pode ser apresentado por escrito. Muitas vezes será preciso também ensinar o que é investigar.

Ao discorrer as etapas do processo investigativo, os alunos desenvolvem a comunicação, a argumentação e as relações interpessoais.

A identificação do problema e o objetivo de resolvê-lo favorece a motivação dos estudantes e abrem horizontes para novas descobertas. Por isso é sempre bom que se parta da realidade, a fim de que a atividade tenha realmente um caráter investigativo e se busque a aprendizagem de conceitos novos. 
O sucesso dependerá do professor, do ambiente gerado na investigação e se ela tiver um objetivo claro. Baseado no modo de pensar e raciocinar do professor, que é mais experiente com as tarefas investigativas, os alunos podem aprender muito sobre aspectos fundamentais desse processo.

Podem abranger diversos temas na matemática como: os números (comparar, ordenar, operar), estatística (recolher dados, organizar, representar) ou cálculos (operar).

Tanto as atividades exploratórias quanto as investigativas são favorecidas com a formação de grupos. Nestes, um líder ajudará a conduzir e minimizar as divergências. Nelas, questões abertas aumentam a chance do envolvimento na atividade. A partir delas formulamse conjecturas, levantam-se dados, testam-se os resultados e cabe ao professor analisá-los, direcionar a aula, desafiar os alunos e pedir justificativas. Nesses processos os registros são de suma importância. É essa a hora da reflexão sobre o trabalho realizado. A fase da discussão desenvolve a capacidade do aluno comunicar-se matematicamente e de refletir sobre seu trabalho e seu poder de argumentação.

A avaliação contínua também faz parte deste tipo de atividade. Cabe ao professor recolher informações desde o primeiro momento da investigação. Inicialmente, ele deve perceber se houve um real entendimento da tarefa e, durante as atividades, é necessário recolher informações sobre o desenrolar do trabalho, procurando entender o que os grupos construíram durante o processo. Muitas vezes, existe uma dificuldade em fazer um registro organizado por parte do aluno, e ainda há limitações na comunicação oral em Matemática. $\mathrm{O}$ professor deve ser paciente, deixando os grupos atuarem com autonomia, sem a necessidade de corrigir cada afirmação, mas favorecendo-os a argumentar sobre o que encontram.

Alguns tipos de avaliação são mais indicados para a atividade investigativa:

- relatórios escritos: dos quais fazem parte não só as conclusões, mas também uma descrição dos processos. Podem-se incluir aí, as questões propostas, a bibliografia utilizada, o modo como os alunos organizam os dados, as conjecturas provadas e não provadas, etc. Um roteiro geral deve ser apresentado aos alunos com os passos que deverão seguir. Nas primeiras vezes que realizam tais atividades, é normal que fiquem confusos. O roteiro deve ser esclarecido e a avaliação pode ser traduzida numa escala quantitativa ( 0 a 10, por exemplo) ou qualitativa (bom, muito bom, etc.). Mas o importante não é a 
escala, e sim, que os critérios fiquem claros, bem como os comentários que o professor escreve aos alunos. Nesses comentários, aparecem dicas, sugestões ou parabenizações. A transparência nos critérios e na escala ajuda na autoavaliação da atividade.

- Observação informal: é um bom meio de conhecer o modo como os alunos reagem às tarefas de investigação, bem como o modo como as interpretam e as estratégias de trabalho que desenvolvem, além, é claro, dos conhecimentos matemáticos que usam. Pode proporcionar muita informação, porém é dificultada pela limitação que o professor enfrenta em salas muito numerosas. Daí a importância dos registros escritos dos grupos ou individuais, em alguns casos.

- Apresentações orais: favorecem a capacidade de comunicação e argumentação dos estudantes. Podem ser individuais ou em grupo. Elas permitem avaliar uma série de objetivos, bem como a oralidade, atitudes e valores, estratégias, processos de raciocínio, e outros. Sua principal limitação é o tempo que consome e acaba se tornando cansativa, se usada com muita frequência.

No decorrer do ano letivo é recomendável ao professor usar estratégias multifacetadas de avaliação.

É importante observar que a tarefa investigativa também pode ocorrer naturalmente mediante uma situação a ser explorada (teste, desafio, exercício), quando o aluno parte para a investigação de questões adicionais e aprofundadas que podem surgir da proposta inicial.

A motivação dos alunos é essencial. Desafios são necessários, mas devem ser propostos de acordo com os conhecimentos e o grau de desenvolvimento do aluno, para não haver desinteresse. A parceria com o professor define o êxito na atividade. A solução é buscada através de pesquisas. $\mathrm{O}$ produto final deve ser apresentado para toda a turma. Com isso, desenvolve-se a iniciativa, a responsabilidade e a persistência.

É importante que, além de descobrir, o aluno saiba justificar a descoberta. O professor não deve fornecer respostas, mas ajudar o aluno a procurar sanar suas dúvidas. De início, muitas vezes, ele não compreende o que são as justificativas, e somente um trabalho continuado com esse tipo de atividade é que poderá levar a uma melhor compreensão da necessidade de se justificar matematicamente as afirmações, em lugar de encarar isto como uma imposição do professor. 
Este tipo de atividade exploratório-investigativa, muitas vezes recebe críticas e argumentos contrários à sua realização. Alguns professores insistem em afirmar que o aluno não tem interesse em investigar e explorar. Na verdade, a função do professor é fazer algo para que o aluno passe a ter o interesse por tal atividade. Outras vezes, afirmam que o aluno tem dificuldade em perceber o que é e como investigar. No início, realmente isto parece difícil e ele pode não saber. Mas é função do professor insistir e criar uma disposição para as investigações. Afirmam, também, que antes de investigar os alunos precisam aprender muitos conceitos. Realmente isso ajudaria, mas eles podem aprender durante o processo investigativo, com as explorações e atividades significativas, que os façam pesquisarem sobre conceitos que são novos para eles.

Que o trabalho de um matemático e de um aluno tenha diferenças, não se tem dúvidas. Mas que existe semelhança entre eles, é claro! O aluno pode agir como um matemático na formulação das questões, na elaboração das conjecturas, na prova dos resultados, na sua apresentação e argumentação, obviamente considerando-se níveis muito mais simples para as possíveis questões levantadas nesse processo.

\subsection{O Benefício da Investigação na Prática Profissional do Professor}

As atividades investigativas apresentam vários pontos positivos, dentre as quais podemos destacar a melhoria no nível de dependência na relação aluno-professor. Percebe-se a evolução dos estudantes no modo de realizar as tarefas. Eles passam a manifestar a criatividade e o entusiasmo. O mais importante: desenvolvem as capacidades de investigar, comunicar e argumentar. Passam a usar conceitos já adquiridos e buscar os outros não conhecidos. É notável o empenho, até mesmo dos alunos mais fracos, nesse tipo de atividade.

Para o professor, pode existir a possibilidade de uma parceria com um professorauxiliar ou um coordenador pedagógico, durante essas tarefas. Com isso, algumas vantagens podem ser percebidas: mais e melhor apoio aos alunos, menor tempo de espera para atendimento e preparação conjunta para as reflexões no final das aulas.

Enfim, cabe ao professor propor tarefas desafiantes e dar um tempo de espera adequado para consolidar os conhecimentos dos alunos; garantir que o trabalho vá fluindo e que seja significativo dentro da disciplina de matemática. Com esta postura, dará 
possibilidades para resolverem os problemas matemáticos, terem os esclarecimentos desejáveis, para haver um crescimento pessoal, aperfeiçoarem-se as instituições, mostraremse novos caminhos para mudanças curriculares e renovações das práticas profissionais.

Vale reforçar que investigação exige racionalidade, clareza nos conceitos e procedimentos. Exige reflexões, debates e críticas. Para o aluno, deve englobar três ações: estudar, conversar e escrever. Para o professor, é preciso sair do discurso para a busca da compreensão. Além de estudar, investigar e conhecer, é preciso concluir. E sempre avaliar, refletir e agir.

É claro que nem tudo deve ser trabalhado por investigação. Porém, esta é uma poderosa forma de construção do conhecimento do aluno e do professor. Vale a esse último articular exercícios, problemas, explorações e tarefas investigativas, dentro da sala de aula e de acordo com os objetivos que se pretende alcançar com cada conteúdo. 


\section{Capítulo 3}

\section{A Proposição de uma Sequência Didática e sua Aplicação}

Após a aplicação da Avaliação de Matemática para o $7^{\circ}$ ano do Ensino Fundamental, da Secretaria de Educação do Estado de São Paulo, em abril de 2012, e reaplicada em agosto do mesmo ano, verificou-se que os alunos dos sétimos anos da escola estadual investigada não apresentavam o domínio em resolver situações problemas envolvendo cálculos de porcentagem. Além disso, 50\% apresentaram dificuldades de converter os dados de uma tabela para um gráfico de setores. Observe-se a questão aplicada, envolvendo porcentagem:

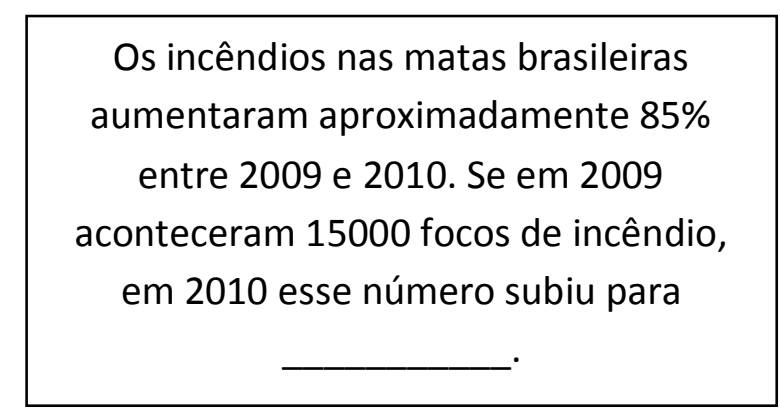

Figura 1 - Questão diagnóstica

A partir dessa análise diagnóstica da prova aplicada pela Secretaria de Educação, constatou-se que tais conteúdos seriam interessantes para serem desenvolvidos através da metodologia de investigações matemáticas, com a qual a professora-pesquisadora teve contato em seus estudos durante o mestrado profissional. Desse modo, foi planejada a sequência didática subsequente, em que os alunos do $7^{\circ}$ ano da turma escolhida deveriam explorar dados e investigar situações familiares a eles, envolvendo o conceito de porcentagem, os recursos de tabelas e gráficos, e que será descrita a seguir. 


\subsection{Atividade: "MOSTRANDO A NOSSA CARA"}

A sequência didática proposta tem como objetivo sanar as dificuldades da turma, constatadas na Avaliação de Matemática para o $7^{\circ}$ ano do Ensino Fundamental. Para isso, buscou-se construir uma sequência flexível, com caráter investigativo, na qual, procurou-se desenvolver habilidades e competências relacionadas ao tratamento da informação e cálculo de porcentagem, com alunos do $7^{\circ}$ ano.

Como atividade de caráter investigativo, os alunos tinham como desafio criar a identidade da turma, retratando matematicamente, seus sonhos, personalidades e expectativas de vida.

O tempo estimado foi de oito aulas, com a previsão da utilização de folhas de sulfite, lápis de cores diversas, régua e o Datashow.

Decidiu-se, então, pela disposição da sala em grupos de quatro ou cinco integrantes, distribuídos de acordo com as afinidades, uma vez que se devia favorecer também o bom relacionamento da sala. A seguir, será descrito como a atividade foi planejada, bem como o seu desenvolvimento.

\subsubsection{Primeira etapa (ou tarefa):}

Iniciou-se a atividade com uma roda de conversa, onde os alunos tiveram contato com os seus objetivos. Foi nesse momento que, além de permear uma pequena abordagem sobre o que é uma atividade investigativa, também se firmou um combinado sobre o comprometimento entre professora e alunos, ou seja, a explicitação do contrato didático ${ }^{1}$. Segundo Brousseau (1986),

Chama-se contrato didático o conjunto de comportamentos do professor que são esperados pelos alunos e o conjunto de comportamentos do aluno que são esperados pelo professor... Esse contrato é o conjunto de regras que determinam uma pequena parte explicitamente, mas, sobretudo implicitamente, o que cada parceiro na relação didática deverá gerir e aquilo que, de uma maneira ou de outra, ele terá de prestar conta perante o outro.

\footnotetext{
${ }^{1}$ Contrato pedagógico, segundo outros autores.
} 
Percebendo-se a necessidade de mostrar o quanto cada um é importante e criar uma identidade para a sala, com características, anseios e opiniões, foi proposta uma coleta de dados, tratamento destes e elaboração de um produto final: a geração de uma carta ao dirigente regional de ensino.

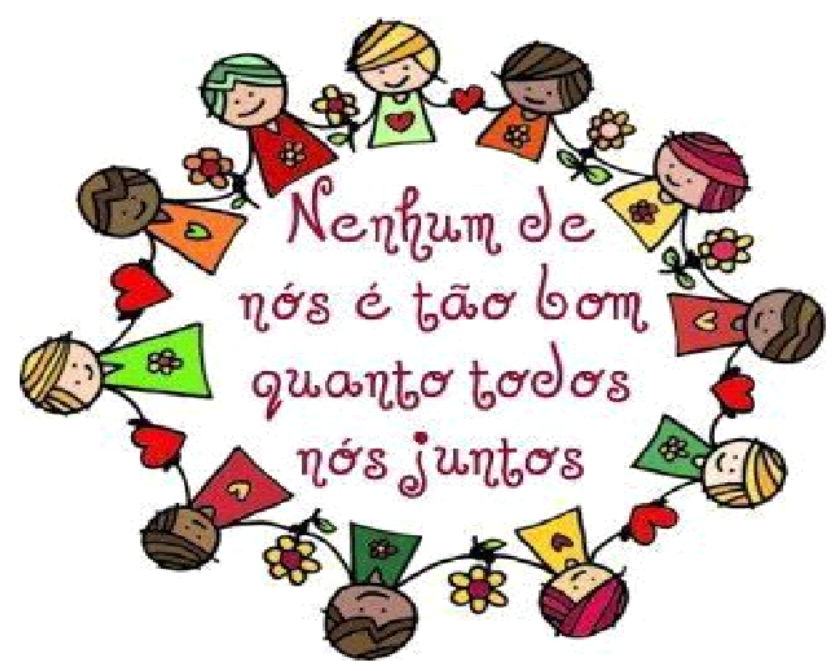

"MOSTRANDO A NOSSA CARA"

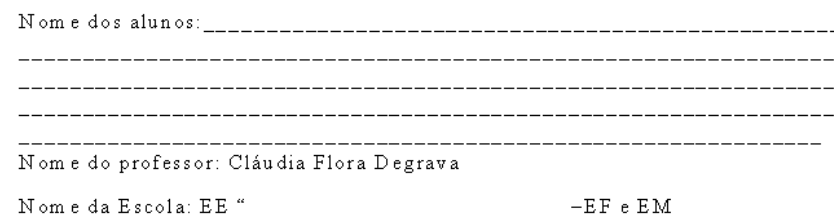

Figura 2 - Cabeçalho da proposta aos alunos.

Após esse momento, foi enfatizada a importância do relatório a ser produzido continuamente pelos alunos (em grupo). Foram informados os critérios a serem abordados no relatório, uma vez que este constituiu etapa avaliativa (Ponte et al, 2003, p. 109-124) . Foi apresentada proposta detalhada dos critérios de avaliação que seriam considerados durante o processo investigativo: 
Tabela 1- Critérios para avaliação do relatório

\begin{tabular}{|c|c|}
\hline \multicolumn{2}{|r|}{ Critérios para avaliação do relatório } \\
\hline NOTA & CARACTERIZAÇÃO \\
\hline 0 a 2,0 & $\begin{array}{l}\text { - Não compreende os conceitos matemáticos; } \\
\text { - Apresenta solução incompleta; } \\
\text { - } \quad \text { Representa os dados coletados incorretamente; } \\
\text { - } \quad \text { Comunica por escrito de forma ineficaz. }\end{array}$ \\
\hline 2,1 a 4,0 & $\begin{array}{l}\text { - Mostra uma compreensão muito limitada dos conceitos utilizados; } \\
\text { - A resposta tem erros de cálculo; } \\
\text { - Falha na identificação dos dados; } \\
\text { - Falha na descrição dos dados; } \\
\text { - Usa gráficos de difícil interpretação. }\end{array}$ \\
\hline 4,1 a 6,0 & $\begin{array}{l}\text { - Compreende alguns dos conceitos matemáticos envolvidos; } \\
\text { - A resposta tem erro de cálculo; } \\
\text { - Solução incompleta; } \\
\text { - Comunicação de difícil interpretação; } \\
\text { - Gráficos pouco claros. }\end{array}$ \\
\hline 6,1 a 8,0 & $\begin{array}{l}\text { - Mostra compreender quase completamente os conceitos matemáticos; } \\
\text { - Usa quase corretamente as terminologias apropriadas; } \\
\text { - Os cálculos estão corretos, com pequenos erros; } \\
\text { - Identifica todos os elementos importantes dos questionamentos; } \\
\text { - Mostra de forma clara o processo de solução; } \\
\text { - A solução é completa. }\end{array}$ \\
\hline 8,1 a 10,0 & $\begin{array}{l}\text { - Mostra compreender completamente os conceitos matemáticos; } \\
\text { - Usa corretamente as terminologias apropriadas; } \\
\text { - Os cálculos estão corretos; } \\
\text { - Identifica os elementos importantes dos questionamentos e mostra total compreensão; } \\
\text { - Mostra de forma clara o processo de solução, com uma estratégia apropriada e } \\
\text { - } \text { sistemática; } \\
\text { - A solução é completa com explicação clara; } \\
\text { - Comunica-se corretamente; } \\
\text { - Apresenta argumentos lógicos e coerentes. }\end{array}$ \\
\hline
\end{tabular}

\footnotetext{
Observação ao aluno: $O$ relatório deverá ser preenchido durante ou ao final de cada aula, por um integrante do grupo, com possibilidade de revezamento. Além disso, é preciso que a produção seja coletiva com a supervisão de todos os membros do grupo uma vez que a atividade não é individual. Faça uso de textos e desenhos caso seja necessário.
} 


\subsubsection{Segunda etapa (ou tarefa):}

Nesse momento, foi necessário fazer com que os alunos pensassem e decidissem quais questionamentos seriam necessários para caracterizar a turma. Foi lançada, então, a seguinte questão: "Para criarmos a nossa identidade, quais informações pessoais o grupo julga importante coletarmos?".

Após uma socialização das ideias, chegou-se à decisão que cada grupo ficaria responsável por levantar uma informação. Os dados a serem colhidos corresponderiam aos seguintes temas:

- Matéria que mais gosta na escola;

- Profissão que gostaria de seguir;

- O que pensa do estudo;

- Expectativas para o futuro;

- Como você é na sala de aula;

- Pontos positivos na sua escola.

\subsubsection{Terceira etapa (ou tarefa):}

Nesse momento, também foi necessário decidir coletivamente como fariam a coleta de dados. Para isso, alguns questionamentos foram feitos:

1. Qual a melhor forma de fazer a coleta dos dados?

2. Como iremos fazer o registro dos dados coletados?

3. Como faremos a distribuição e organização do trabalho?

Decidiram que os dados seriam coletados no pátio da escola, com os alunos daquela sala do $7^{\circ}$ ano, e que os grupos fariam um rodízio para se entrevistarem e conseguir coletar todos os dados. 


\subsubsection{Quarta etapa (ou tarefa):}

Realizada após a coleta de dados, essa foi uma etapa importante, onde eles precisavam ser interpretados, calculados e apresentados. Eis as questões apresentadas aos alunos:

1. Após coleta dos dados, quais são as formas de apresentá-los para melhor compreensão do nosso perfil, por uma pessoa de fora da nossa sala?

2. Como faremos a distribuição e organização do trabalho?

Decidiu-se, então, pelo cálculo da porcentagem dos dados colhidos. E logo a seguir, pela apresentação em tabelas e gráficos de setores.

Uma vez discutidas essas questões, os alunos partiram para resoluções matemáticas com o objetivo de apresentar os resultados da melhor forma. Fizeram uso de estratégias para cálculos e representações. A professora norteou o desenvolvimento das atividades, atendendo grupo por grupo.

\subsubsection{Quinta etapa (ou tarefa):}

Fazendo uso do Datashow, os alunos, mediados pela professora e de posse de seus relatórios, deveriam construir uma carta ao dirigente regional de ensino. Nela, apresentariam suas características, suas dificuldades e avanços, seus pontos fortes e seus sonhos. Fariam uso dos dados calculados. Ao final da atividade, a carta redigida seria entregue pessoalmente na Diretoria de Ensino, à qual a escola pertence. Isso tudo em um momento de descontração e parceria.

Entretanto, não foi possível usar o Datashow para a execução desta etapa, pois o equipamento não funcionou. A professora-pesquisadora teve de improvisar uma solução para a continuidade da tarefa, que foi redigir a carta coletivamente na lousa. Os diversos grupos fizeram cópias, manualmente, da carta que ia sendo construída e, ao final um grupo foi escolhido para apresentar sua cópia. 
No próximo capítulo, serão apresentados detalhes da aplicação e desenvolvimento desta sequência didática, bem como a análise da participação dos alunos e de suas aprendizagens. 


\section{Capítulo 4}

\section{A Análise do Caso de Aplicação}

Afinal, qual é a importância de todo esse estudo? Neste capítulo far-se-á uma síntese das ações executadas em sala de aula e uma reflexão sobre as melhorias possibilitadas por este tipo de atividade. Além disso, evidenciar-se-á a questão do desenvolvimento pessoal, tanto do aluno quanto da profissional, inserido dentro de uma instituição escolar, numa sala de aula real, comtemplando, assim, os objetivos da pesquisa-ação: melhoria no nível de aprendizagem, avanço profissional da docente e o aperfeiçoamento das instituições.

\subsection{O Desenvolvimento dos Alunos com a Atividade Investigativa}

\subsubsection{O início de tudo}

O momento dos esclarecimentos iniciais, acerca do contrato didático e do relatório a ser feito, foi muito importante para o bom direcionamento da atividade. Através de uma roda de conversa, a professora iniciou o processo investigativo, apresentando os objetivos da atividade e suas expectativas pessoais. Decidiu-se pela formação dos grupos, de uma forma harmoniosa, já prevalecendo um enfoque sobre as relações interpessoais. Evitou-se, nesse momento, a imposição de regras e condutas, mas foi negociado um comportamento participativo nas atividades.

A professora detalhou o desenvolvimento da atividade e os alunos foram informados que deveriam criar a identidade da turma, promovendo, inicialmente, a construção de um contrato didático.

Formaram-se os grupos e discutiram-se maneiras de agir durante a realização das atividades. Em seguida, de posse dos relatos, os alunos socializaram as ideias chegando a uma redação coletiva do contrato acordado, mediados pela professora, para um bom andamento das aulas. Isso pode ser constatado na figura 3: 


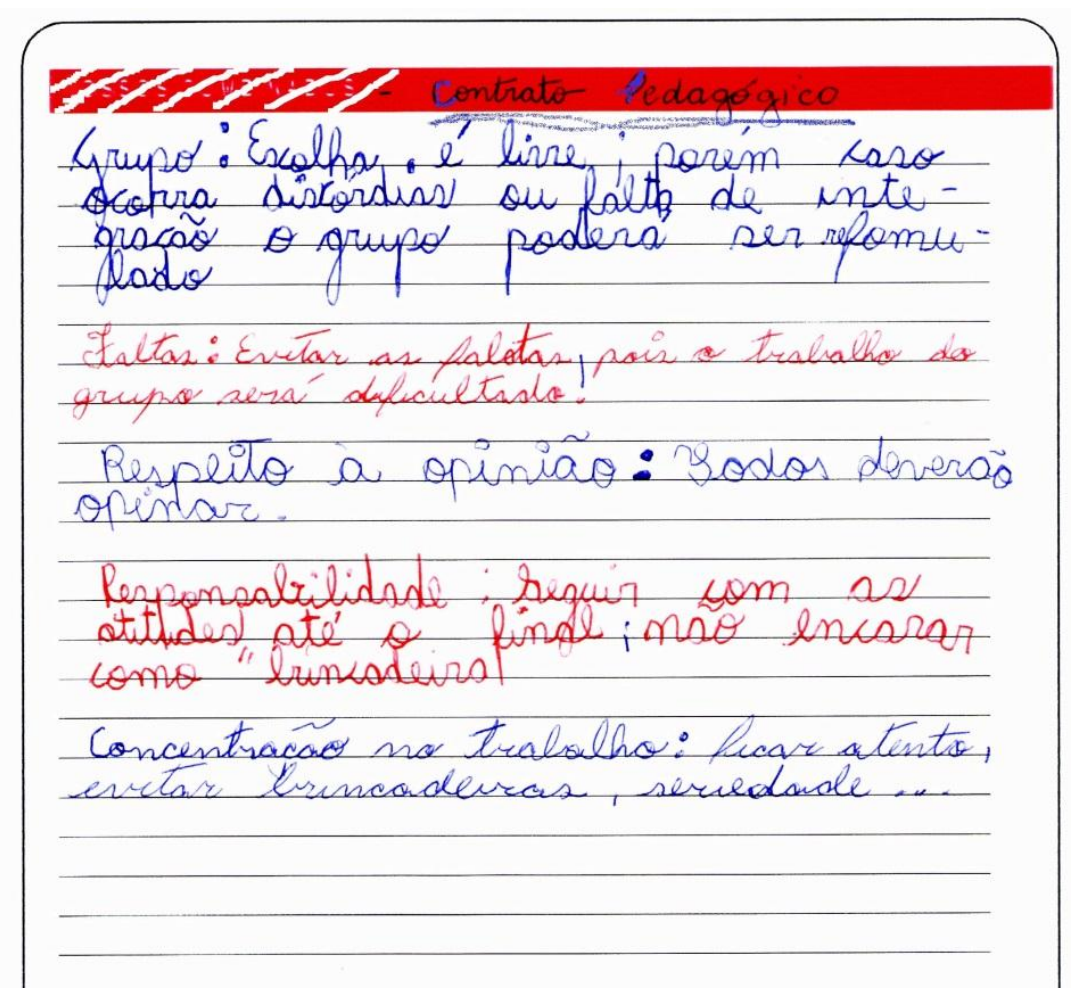

Figura 3 - Contrato Didático negociado.

A qualidade da educação oferecida nas escolas públicas vem ganhando importância e procura-se cada vez mais a excelência. Com a elaboração do Currículo do Estado de São Paulo, na área de Matemática e suas Tecnologias, buscou-se garantir a implantação da Proposta Pedagógica, a fim de aprimorar nos educandos as capacidades de agir, refletir e atuar no mundo em que vivem, além de interpretar dados e se relacionar com outros indivíduos, ampliando aspectos de sua formação cultural, social e para o trabalho. É notável também, a preocupação que se tem em despertar a autonomia do aluno, que deve buscar sua aprendizagem contínua.

De acordo com a Proposta Curricular do Estado de São Paulo (São Paulo, ano 2012, página 30),

\footnotetext{
A Matemática nos currículos deve constituir, em parceria com a língua materna, um recurso imprescindível para uma expressão rica, uma compreensão abrangente, uma argumentação correta, um enfrentamento assertivo de situações-problema, uma contextualização significativa dos temas estudados.
} 
Percebe-se a formulação de todo Currículo tendo como base três eixos norteadores de competências:

- Eixo expressão/compreensão: é a capacidade de expressão do eu, de compreensão do outro, incluindo a leitura de todos os gêneros e a compreensão de fatos e fenômenos. A Matemática, dentro deste eixo, busca a expressão e compreensão da realidade.

- Eixo argumentação/decisão: é a capacidade de argumentar, analisar e articular as informações adquiridas de diversas formas, buscando as tomadas de decisões e realização de ações efetivas. A Matemática, dentro deste eixo, proporciona o desenvolvimento do raciocínio lógico e da análise racional, buscando as conclusões pertinentes ao mundo em que o educando está inserido.

- Eixo contextualização/abstração: é a capacidade de contextualizar conteúdos estudados na escola, significando-os em especial no mundo do trabalho. É destaque da Matemática, neste eixo, a capacidade de trabalhar com o concreto e o abstrato.

Apesar do discurso do documento citado no parágrafo anterior, pouco se nota a prática de atividades investigativas, no sentido aqui estudado, nos exemplares dos "Cadernos do Aluno" de Matemática do Ensino Fundamental. A nosso ver, como foi tratado no capítulo 2, tal prática auxiliaria muito o desenvolvimento da autonomia dos alunos, do poder de expressar e compreender, argumentar e decidir, transpondo o concreto para o abstrato e relacionando ideias abstratas com decisões da vida diária.

Talvez pela ausência desse tipo de atividades nas práticas escolares cotidianas, a professora-pesquisadora tenha encontrado dificuldades iniciais em esclarecer e engajar os alunos na investigação. Novamente, através de uma roda de conversa, foram necessárias mais algumas explicações relacionadas ao como agir e reagir.

Também a prática do relatório foi introduzida, uma vez que isto não era hábito dos alunos deste $7^{\circ}$ ano. De posse da tabela 1, do capítulo 3, fez-se uma leitura compartilhada dos "Critérios para Avaliação do Relatório" e houve a motivação para que os alunos buscassem aperfeiçoar cada vez mais os seus registros. A tabela, como pode ser visto na página 38, relaciona a nota do grupo no desenvolvimento da atividade, com os critérios alcançados nos 
registros escritos. Mesmo apresentando uma escala numérica de valores, a avaliação não deixa de ser qualitativa, uma vez que o desenvolvimento da aprendizagem é direcionado para um todo, desde a evolução das relações interpessoais, do crescimento matemático, até registros.

Os grupos receberam várias instruções e a respeito do relatório, combinou-se pelo registro diário, com reescrita ao final de todas as tarefas.

\subsubsection{Quais informações coletar?}

Mediante a proposta apresentada aos alunos e todo um trabalho pela frente, onde ao final, todos teriam a identidade da turma formada, eis a questão: Quais informações deveriam coletar?

De início, em cada tarefa, buscando fazer uso de registros, os alunos descreviam o objetivo daquilo que era proposto. No começo, foram mais auxiliados pela professora, mas ao final, passaram a registrar de forma espontânea, mostrando a evolução alcançada com a investigação matemática.

Por exemplo, para a primeira tarefa, um grupo apresentou o registro do seguinte objetivo: "Descobrir quais informações deverão fazer parte da coleta de dados".

Inicialmente discutidos em grupo, e em seguida socializados os registros, decidiu-se com a turma sobre as questões a serem levantadas, com as quais identificariam melhor o perfil da sala, que estão detalhadas na tabela 2, a seguir:

Tabela 2 - Assuntos decididos para comporem o levantamento de dados

\begin{tabular}{c}
\hline ASSUNTOS A SEREM LEVANTADOS \\
\hline Profissão pretendida para o futuro \\
Matéria preferida durante as aulas \\
Como se comporta em sala de aula \\
Expectativas para ofuturo \\
Qual a importância dos estudos \\
Como age na escola \\
Pontos positivos de sua escola \\
\hline
\end{tabular}


Embora a última questão escolhida, nesta tabela, não sirva para caracterizar a turma em questão, notou-se um grande entrosamento dos alunos de cada equipe, querendo tomar decisões, opinando e observando, como pode ser visto no relatório do grupo 6:

"Prestamos atenção, demos opiniões; Luana ajudou bastante; Priscila não escreveu, mas a maioria das coisas ela foi falando; Vinícius não ajudou, mas observou; Emily e Edilaine também ajudaram."

Isto evidencia como as relações interpessoais foram se aperfeiçoando ao longo do desenvolvimento da atividade investigativa, promovendo a participação efetiva de todos os alunos. A última questão da tabela 2 também evidencia uma atitude reflexiva em relação à sua participação na escola.

\subsubsection{Coletando e organizando os dados}

Esta foi uma etapa muito importante para o trabalho, ao levantar as informações úteis para o desenvolvimento da proposta. Também apresentou o desafio de levar os estudantes a decidirem sobre como essas informações seriam levantadas. Essa e outras dúvidas surgiram durante o processo, o que é característico das atividades de investigação, e que auxilia no desenvolvimento da autonomia dos educandos para futuras tomadas de decisão. Sempre reunidos, as decisões eram tomadas e os alunos chegavam à melhor opção.

Para a coleta dos dados, decidiu-se que a mesma seria realizada no pátio da escola, e cada grupo, de posse de um assunto, faria o levantamento das informações necessárias, por meio de entrevistas com outros grupos, havendo um revezamento dos mesmos, para isso. A divisão dos assuntos ocorreu da seguinte forma:

Tabela 3 - Assuntos a serem abordados por cada grupo

\begin{tabular}{cc}
\hline GRUPO & ASSUNTO \\
\hline 1 & Profissão pretendida para o futuro \\
2 & Matéria preferida durante as aulas \\
3 & Como se comporta em sala de aula \\
4 & Expectativas para o futuro \\
5 & Qual a importância dos estudos \\
6 & Como age na escola \\
7 & Pontos positivos de sua escola \\
\hline
\end{tabular}


A atividade no pátio aconteceu conforme o planejado, em uma aula de 50 minutos, e observou-se que as relações aluno-aluno foram aí fortalecidas.

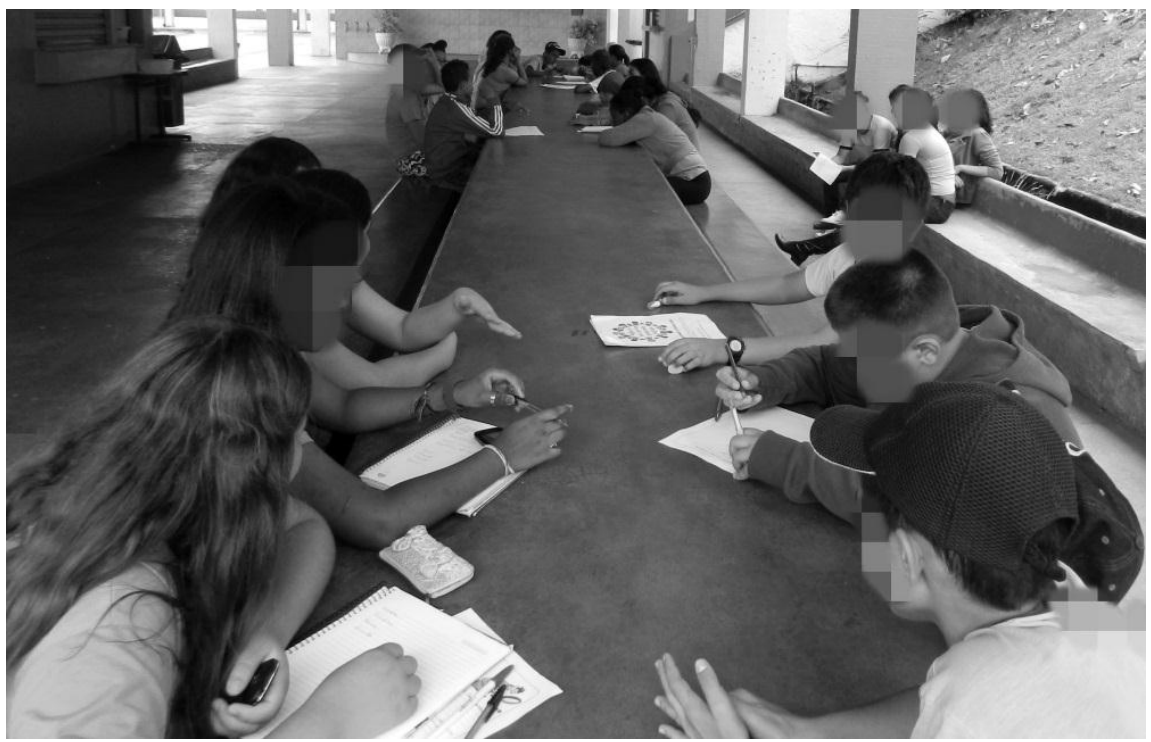

Figura 4 - Momento da coleta de dados

Em seguida, refletiu-se sobre a melhor forma de registro das informações coletadas. As anotações foram realizadas e a professora, norteando a atividade, fez com que cada grupo percebesse os equívocos, refazendo a coleta de dados, nos casos necessários.

O grupo 2 optou por registrar as respostas de sua pergunta separadamente para cada entrevistado e depois realizou uma síntese com a contagem registrada do lado direito da folha 5 (figuras 5 e 6). As letras indicam a inicial da disciplina preferida e os traços indicam o número de alunos que optaram por elas. 
D) TRABALHO DO GRUPO: COLETANDO AS INFORMAÇÕES

grupo 1 total de entrenea

Cina = Curte tado 29

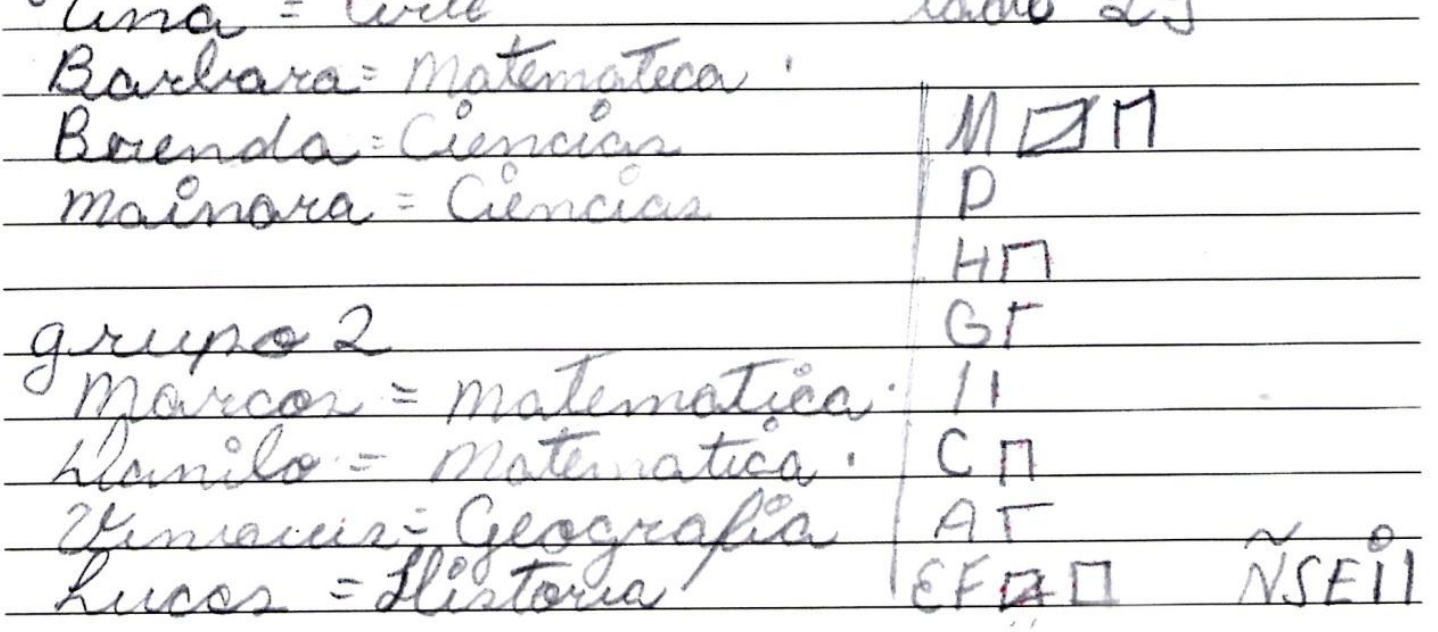

grupo 4

Laluana
mario
natali
Karina
grapo it

Luin Hennerine matematioa

fose ternondo- firina

grapan 6

$$
\begin{aligned}
& \text { Pricila = Histora } \\
& \text { Luana = Cpivo } \\
& \text { Enely ofisian } \\
& \text { iruvius S-glistoria }
\end{aligned}
$$

Figura 5 - Registro da coleta de dados, feita pelo grupo 2, sobre a matéria preferida na escola

49 


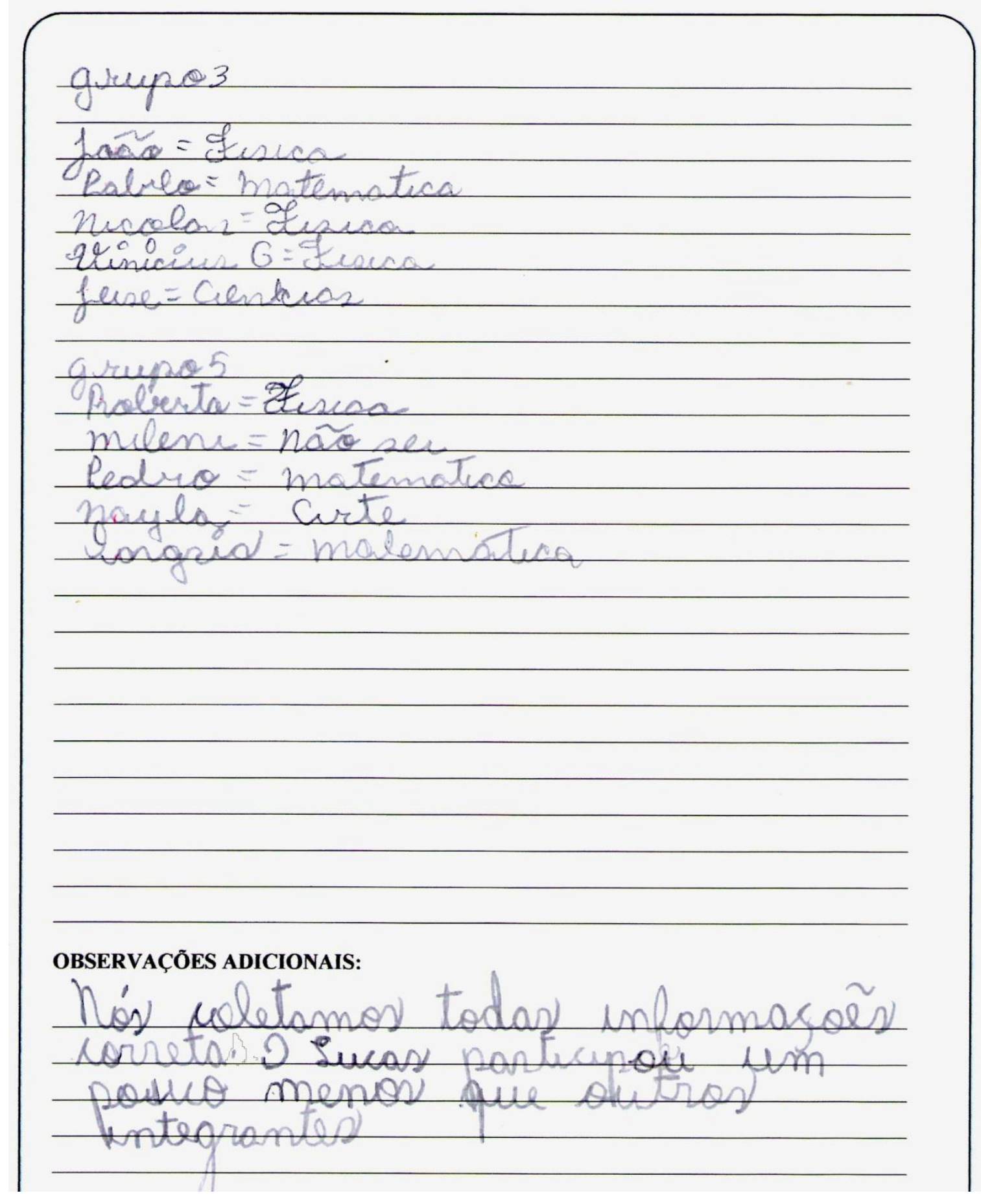

Figura 6 - Continuação dos registros do grupo 2, com observações adicionais.

Dois grupos (1 e 4), fizeram a primeira parte do registro de forma semelhante ao grupo 2, porém não realizaram a síntese. Isso foi feito somente após a intervenção da professora.

Já o grupo 3, fez registros muito genéricos, que não permitiam uma síntese numérica e foi orientado a refazer os registros originais, como mostra a figura 7, a seguir: 


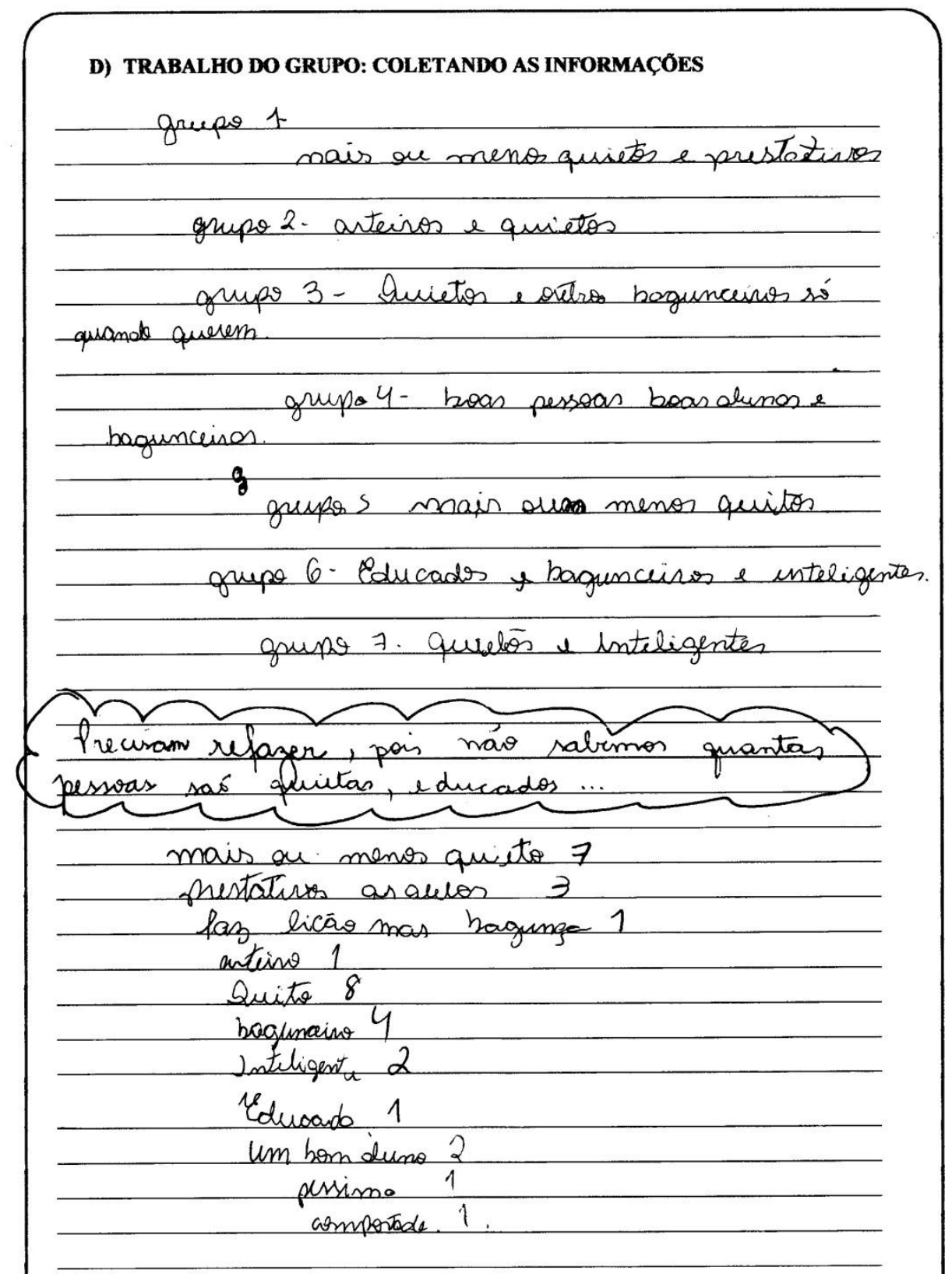

Figura 7 - Registro da coleta de dados, feita pelo grupo 3, sobre o comportamento dos alunos.

O grupo 7 fez os registros e a síntese semelhantes aos do grupo 2, porém permitiu que cada entrevistado respondesse a duas características, o que fez com que o número total de respostas fosse o dobro dos demais e isto teve que ser considerado para as tarefas subsequentes. Já o grupo 6 também permitiu que alguns alunos respondessem a mais de uma informação, porém sem uma regularidade, o que fez com que tivessem que excluir alguns aspectos do registro original. $\mathrm{O}$ grupo 5 apresentou o registro mais enxuto, somente com a síntese numérica das respostas obtidas. 


\subsubsection{Aprendizagem sobre porcentagem, tabelas e gráficos (além de outros conhecimentos matemáticos).}

Com o objetivo de decidir o que seria feito com os dados coletados, os grupos se reuniram novamente e levantaram as melhores formas de apresentação matemática do resultado. Decidiu-se, então, que a melhor forma de apresentar o resultado obtido seria através de porcentagens, com organização em tabelas e construção de gráficos.

Iniciou-se pela construção de tabelas, com valores numéricos para indicar a quantidade de escolhas. Percebeu-se, então, que alguns grupos precisariam reformular novamente a coleta, pois as informações não eram coerentes com o número de alunos da sala. Fez-se, então, uma análise do erro, com busca da solução. Na matemática, conforme Pinto (2000), o "erro" não deve ser eliminado bruscamente. Todos nós temos limitações e precisamos de estímulos e compreensão para despertar nossos interesses, e a detecção do erro é uma etapa importante para conceitos e ações.

Livros didáticos foram consultados para direcionar o produto a ser construído e reconstruído, ou seja, as tabelas.

Dando sequência, o momento fundamental e muito esperado foi o cálculo dos valores percentuais, relacionados às informações colhidas, que determinavam as características da sala. Sempre com função mediadora, em especial nesse momento, a professora atendeu a todos os grupos, encorajando-os e direcionando-os.

Cabe ressaltar que nesse momento, como atividade investigativa, os alunos não tinham um caminho a ser seguido, apenas um objetivo a ser alcançado. Várias estratégias foram utilizadas e o fato de grande parte dos grupos terem feito uso da regra de três para o cálculo das porcentagens, surpreendeu positivamente a professora-pesquisadora, pois esse conteúdo (regra de três), abordado com a turma em meses anteriores à aplicação da sequência didática, não havia sido relacionado com a porcentagem. Percebeu-se também, a familiarização que possuíam a respeito de valores inteiros, tais como as quantidades correspondentes o $100 \%$, a metade e a metade da metade ( 50 e $25 \%$ respectivamente), dentre os dados coletados.

A seguir, são apresentadas, as estratégias de cálculo, adotadas por cada grupo, após algumas buscas espontâneas realizadas em livros didáticos e relações obtidas com outros conteúdos, disponíveis no próprio caderno ou no material intitulado "Caderno do Aluno", da Secretaria de Educação do Estado de São Paulo (Vol.3 matemática). 
Tabela 4 - Estratégias adotadas por cada grupo, para o cálculo de porcentagem.

\section{GRUPO}

\section{ASSUNTO}

1

Regra de três para calcular a porcentagem de um voto e multiplicações para mais de um voto.

Multiplicaram o número de votos por 100 e a seguir dividiram pelo total de alunos participantes da pesquisa (29).

Dividiram o número de votos de cada escolha pelo total de participantes e a seguir multiplicaram por 100.

Dividiram100\% pelo número de participantes, descobrindo o percentual de um voto. A seguir fizeram uso de multiplicações.

Regra de três.

6

Regra de três.

Cálculo mental e operações diversas, semelhantes do grupo 4, porém sem detalhamento.

Uma das vantagens das atividades investigativas pôde ser observada na diversidade de estratégias abordadas, de acordo com um entendimento real da situação. É nesse sentido que se dá a aprendizagem significativa, muitas vezes almejada e não alcançada na apresentação de modelos de problemas e/ ou exercícios de fixação.

Fato curioso chamou a atenção da professora durante a realização desta tarefa. Em determinado grupo, Lucas, que tinha sido excluído por parte dos colegas, apresentou um resultado surpreendente nesta etapa. Este educando, durante a sequência didática, acabou trocando de grupo, por incompreensão dos outros alunos, que acostumados com atitudes indisciplinares deste, acabaram por excluí-lo. Ansioso por querer participar, procurou um grupo que necessitava de ajuda e se realizou nos cálculos, mostrando sua capacidade e importância. Segue o relato de como esse novo grupo de Lucas, liderado por ele, realizou a atividade.

Lucas, liderando a solução:

... "Cada aluno votou duas vezes. Como 58 é o total de votos, eu dividi 100 por 58. Daí eu achei o nosso último item que tinha apenas 1 voto, que deu 1,6\%. Eu fui fazendo vezes, vezes, e fui achando as porcentagens dos outros itens. "... 
Os outros alunos prestavam atenção e, aparentemente concordando com Lucas, mas sem compreender muito o seu raciocínio, iam anotando suas orientações.

Este grupo, de início, apresentou maior dificuldade para resolver a etapa que envolvia os cálculos de porcentagens e a iniciativa do aluno Lucas motivou-os a continuar, mesmo, talvez, sem terem compreendido totalmente sua proposta.

Para finalizar, realizou-se a construção dos gráficos de barras ou setores, definidos pelo grupo. Para isso, após investigações, utilizaram-se da regra de três e instrumentos de medidas (réguas e transferidores). Eis o resultado obtido por um dos grupos, após sentirem necessidade de completar a tabela:

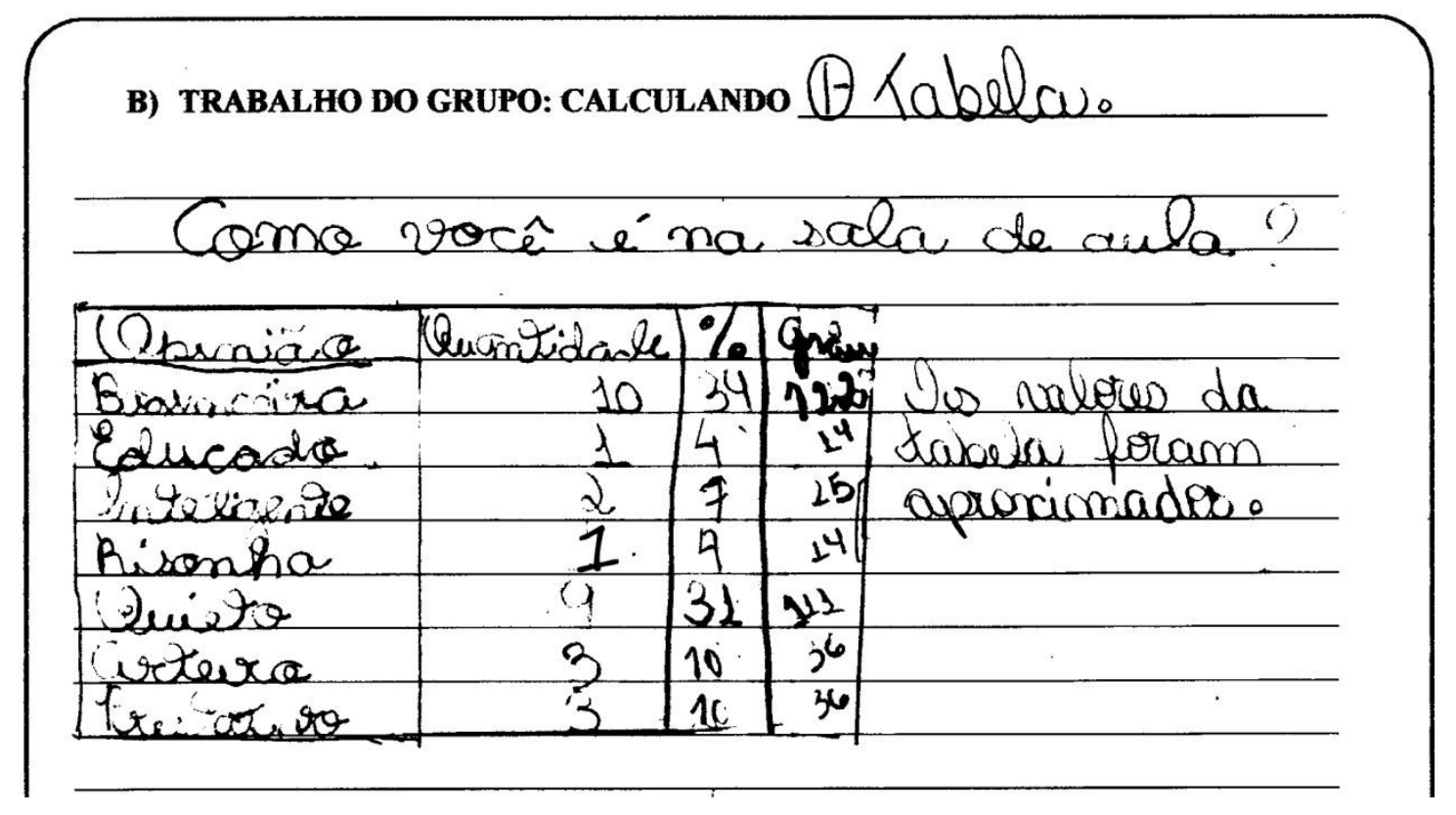

Figura 8 - Tabela construída pelo grupo 3.

Observa-se que as categorias escolhidas pelos alunos, na figura 8, poderiam apresentar intersecções entre si (um mesmo aluno poderia ter várias dessas características), porém ficou esclarecido que eles optaram por uma única qualidade que fosse a mais representativa de sua auto-percepção, ou seja, aquela que mais bem representava sua pessoa. Eles também não escolheram, durante o processo, variáveis quantitativas que pudessem caracterizar a classe. Esse foi um lapso da professora-pesquisadora, que os poderia ter induzido a essa escolha e 
aproveitado tais dados quantitativos numa exploração futura para abordar conceitos da estatística. É, portanto, um aperfeiçoamento que poderá ser feito em futuras aplicações dessa sequência didática.

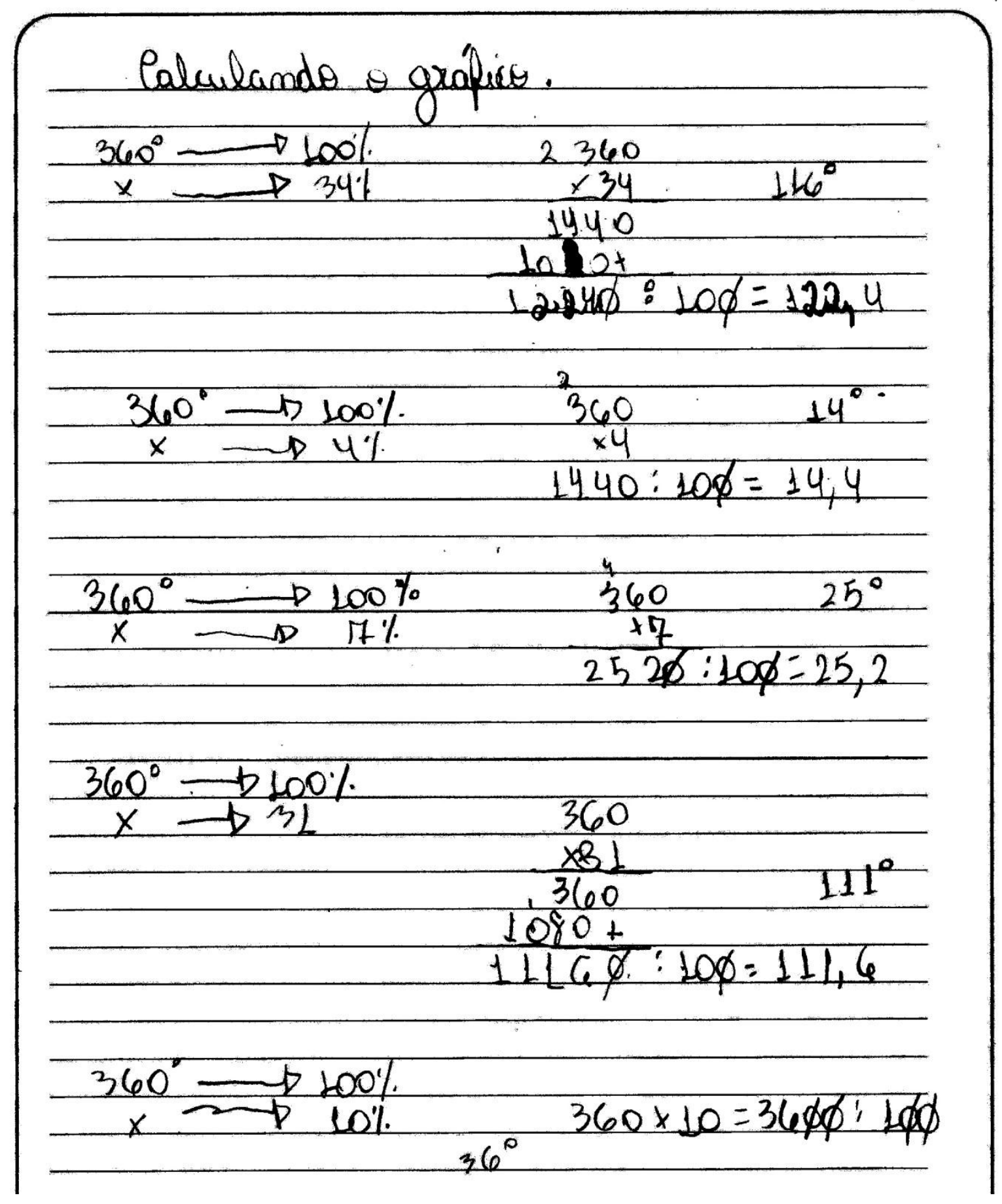

Figura 9- Cálculos para a construção do gráfico, pelo grupo 3. 


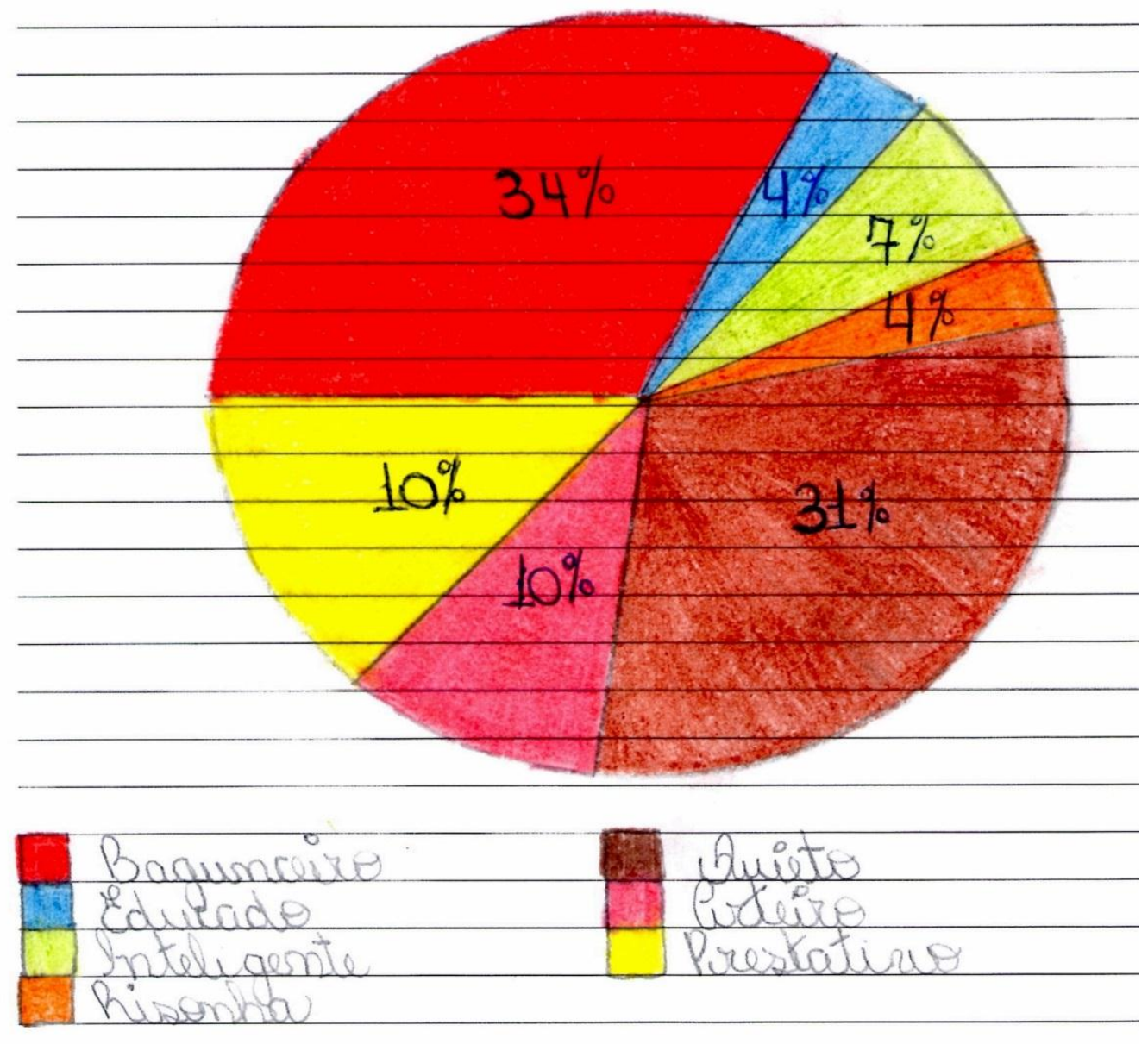

Figura 10- Gráfico de setores “Como é seu comportamento em sala de aula?”, do grupo 3.

Essas figuras mostram como o grupo 3 fez um registro detalhado de todo o processo de desenvolvimento da tarefa, evidenciando melhorias neste quesito em comparação com os registros iniciais.

Em síntese, os registros desta etapa, evidenciaram que todos os grupos foram capazes de relacionar o conceito matemático de porcentagem com as representações em tabelas e gráficos, bem como sobre a representação geométrica de setores e a medida de ângulos em graus. Não foi possível realizar avaliações individualizadas, posteriores à aplicação desta atividade investigativa e alguns alunos podem não ter alcançado total compreensão destas relações. Porém, conforme foi observado durante o desenvolvimento desta etapa, a grande maioria dos alunos estava por dentro das ideias discutidas, pois vários desejavam auxiliar seu grupo com os registros. 


\subsubsection{Melhoria com a expressão oral e escrita}

Após todo o trabalho matemático realizado, concluiu-se a sequência com atividades interpretativas e de expressão.

Cada grupo, de posse de seus dados e gráficos, finalizaram seus relatórios, como foi previsto em 4.1.1. Evidenciou-se, nesse momento de registros, a grande defasagem que estes alunos apresentam na expressão escrita. Mesmo com a supervisão de vários integrantes do grupo, os erros ortográficos e de concordância aparecem em quase todas as etapas. Inicialmente apresentavam maior resistência na escrita, dependo de um início realizado pela professora. Já no final, apesar dos erros ortográficos, conseguiram se expressar mais espontaneamente.

Acredita-se que apenas com várias atividades desse tipo seria possível garantir um avanço desejável e isso evidencia o grande potencial das atividades investigativas para a aprendizagem e o desenvolvimento mais global de todos os estudantes.

Até mesmo alunos considerados mais fracos participaram da atividade, demonstrando ter capacidades muitas vezes não percebidas nas aulas tradicionais. Um dos alunos, considerado semialfabetizado por todos os professores da turma, participante da sala de recursos, foi redator de um dos relatórios, apresentando apenas erros semelhantes aos demais grupos. Este era um participante do grupo 7, que apresentou dificuldades para o cálculo de porcentagens e foi conduzido nesta etapa pelo aluno Lucas. Porém, percebeu-se seu envolvimento com a tarefa e avanços significativos em sua escrita nos registros.

Também, promovendo a interdisciplinaridade, houve a produção de um texto coletivo, cujo gênero era carta pessoal. A finalidade de tal atividade era buscar a compreensão de todos os dados, socializando com a turma as informações obtidas por cada equipe. Houve um enfoque na interpretação desses dados e na valorização dos alunos como indivíduos de uma sociedade, com sonhos e expectativas.

Através de uma nova roda de conversa, e de posse de todos os dados e relatórios, os alunos opinavam sobre a escrita realizada coletivamente, na lousa e discutiam os resultados numéricos. Um redator de cada grupo, que se propunha espontaneamente, fazia cópias da produção. Foi trabalhado, neste momento, a questão da estrutura textual, a ortografia, coesão e coerência, dentre outros aspectos. Tal carta foi finalizada e entregue pessoalmente ao Dirigente Regional, em uma visita à Diretoria de Ensino. Eis a produção obtida: 

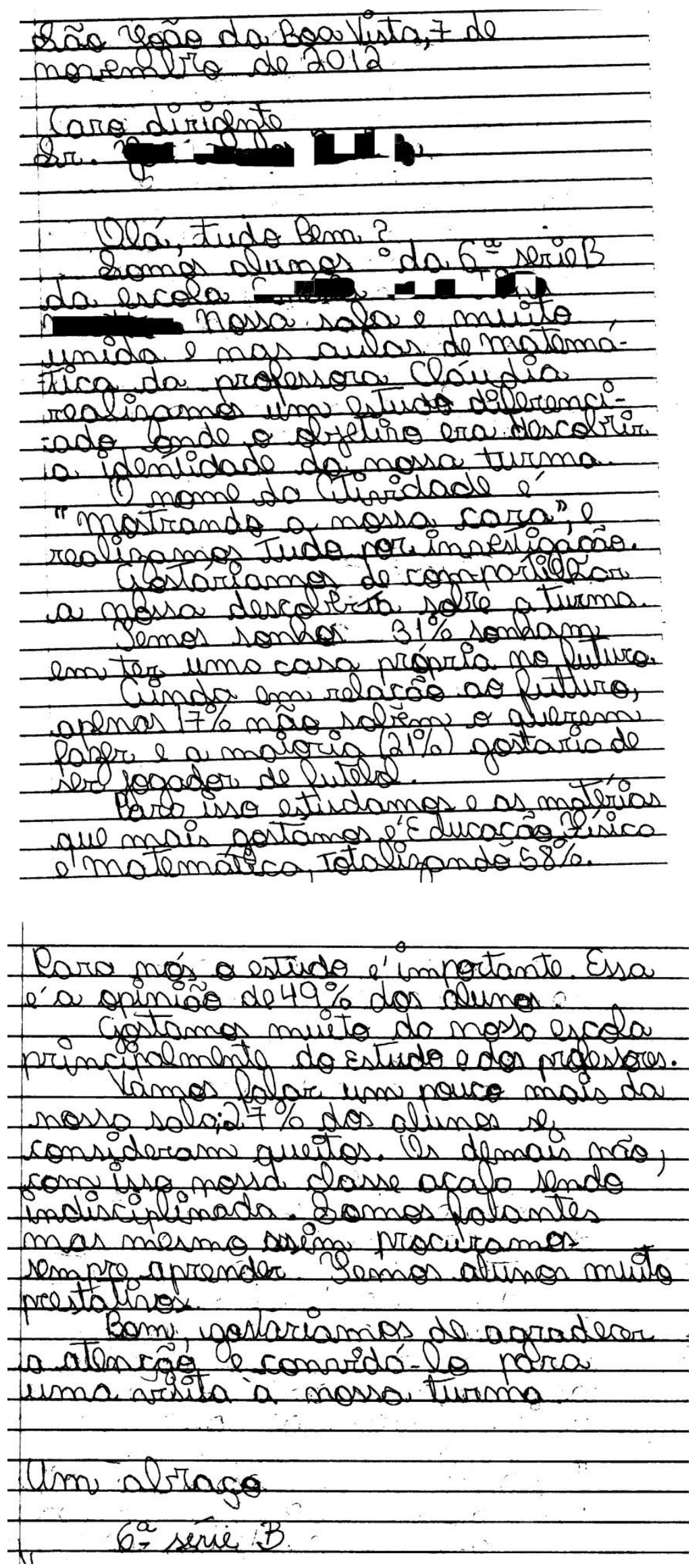

Figura 11- Carta ao Dirigente. 


\subsubsection{Melhoria no relacionamento interpessoal dos alunos}

Após realização de tal atividade, extrapolando o previsto de oito aulas para doze, a professora-pesquisadora, em conjunto com a equipe gestora, refletiu sobre os avanços comportamentais dos alunos durante o período.

Durante as aulas, pequenos momentos de discórdia ocorreram entre os discentes, porém nada semelhante ao que já ocorrera em outras ocasiões. Em um ambiente heterogêneo, opiniões divergentes ocorrem a todo o momento. Porém estes alunos adquiriram, durante o processo, discernimento suficiente para superá-las. O respeito se deu da melhor forma possível, facilitando o desenvolvimento do trabalho, o que mostra que o contrato didático negociado era cumprido na maioria do tempo.

Felicitou-se a professora-pesquisadora, uma vez que era um dos objetivos de sua proposta, a melhoria do relacionamento nessa sala. Escolheu-se esta turma, na qual traços de indisciplina eram marcantes, atrapalhando as relações pedagógicas e avanços no conteúdo matemático. Ao final, esta característica foi minimizada prevalecendo os laços afetivos entre alunos e entre professora-alunos, o que será descrito a seguir. Isso também favoreceu o maior engajamento dos alunos na elaboração dos raciocínios matemáticos, embora alguns ainda apresentassem maiores dificuldades que outros.

\subsubsection{Como ficou a relação professora-alunos}

Além do benefício alcançado nas relações pessoais entre os alunos, a aplicação da atividade promoveu o avanço na relação professora-alunos.

Maximizando-se os contatos, uma vez que a ação da professora passou a ser direta com os grupos, facilitaram-se as trocas de experiências, além de se estabelecer um maior nível de confiança entre ambos os lados.

O contrato didático negociado - os combinados - veio a fortalecer o respeito necessário. A valorização do trabalho fez com que a seriedade fosse mantida.

Um fato marcante ocorreu, logo após o término da aplicação, fora da sala de aula. Uma aluna, que nesse dia apresentou comportamento inadequado para um ambiente escolar, quando todos temiam por seus atos, aceitou apenas a aproximação desta professora- 
pesquisadora, contando suas dificuldades e desesperos do momento de tais atos inapropriados. Isto evidenciou, mais uma vez, como as relações interpessoais foram fortalecidas e como o processo investigativo propiciou confiança desta aluna para com a professora-pesquisadora.

O término do ano letivo foi de grande parceria entre todos, ficando as expectativas para o futuro, diferentemente do início, em que até mesmo para abrir um material, dispendiase certo esforço da professora para a realização da tarefa.

\subsection{Formação Profissional Docente}

Mediante o desafio de promover a aprendizagem matemática em seus alunos, após leituras sobre a metodologia investigativa e análise de diversos materiais didáticos, a professora construiu sua própria sequência didática fazendo uso de investigações.

Após a aplicação, efetivou-se a eficácia do trabalho, promovendo a satisfação pessoal da profissional.

Sempre em busca de novas situações de aprendizagem, a professora, provou, ao final, que a aplicação de atividades investigativas é possível em salas de aula desafiadoras, onde a indisciplina é constante, o número de alunos não é reduzido, e as defasagens de aprendizagem existem frequentemente.

Além da possibilidade de aplicação, melhor ainda é a possibilidade de aprendizagem. Isso também foi notado, mas nada seria possível se não existisse, além da motivação pessoal da docente, a aquisição do conhecimento pedagógico sobre o contrato didático negociado, o qual direcionou o modo de agir dos educandos. Surpresas positivas foram surgindo, o que garantiu maior segurança na aplicação da sequência didática.

Com o desenvolvimento e a redação deste trabalho, a professora aprendeu, ainda, a refletir continuamente sobre a sua ação didático-pedagógica, com os estudos sobre a pesquisa qualitativa. É real a necessidade da flexibilização no planejamento e execução das atividades, com retomadas constantes. Mediante a realização dos registros realizados pelos alunos, pôde melhor conduzir a sala nas aulas subsequentes. Através de orientações nos registros, embora parciais, os alunos refletiam e mudavam procedimentos e posturas adotadas em aulas 
precedentes. Esta prática, não comum em aulas anteriores desta professora, auxiliou muito na condução das aulas investigativas.

Essa maneira nova de ensinar, diferente do tradicional, sem modelos e exercícios de fixação, mostrou a necessidade de adequações e da busca constante por novos conhecimentos, por parte dos professores, em especial desta, que na busca por inovações, veio aprofundar-se nesta nova metodologia.

De acordo com Shulman (1986), os professores têm conhecimento do conteúdo especializado que ensinam. Porém, para a excelência em sua prática, seriam necessários diferentes tipos de conhecimentos, incluindo o específico, o conhecimento pedagógico do conteúdo e também o conhecimento curricular.

Ao aplicar esta sequência didática, a professora-pesquisadora pode dizer que houve um desenvolvimento de seu conhecimento pedagógico do conteúdo, bem como dos conhecimentos curriculares, ao interpretar a Proposta Curricular do Estado de São Paulo, à luz de uma nova ideia metodológica e de sua propositura na prática de uma sala de aula considerada desafiadora. Esse conhecimento é construído pelo professor ao ensinar. É o real conhecimento do conteúdo, que inclui, além da compreensão sobre um tópico de uma disciplina, também os procedimentos e as técnicas necessárias para se alcançar a aprendizagem, aqui entendida de modo que ocorra significativamente para os estudantes.

Embora lecionar envolva quatro requisitos - conhecimentos sobre os conteúdos específicos, sobre diferentes materiais e estruturas de ensinos, sobre a literatura referente aos processos de ensino e aprendizagem e a sabedoria da prática - este ultimo é o único conhecimento de autoria do próprio professor. É aprendido em sua atuação profissional e necessário para a construção do conhecimento pedagógico do conteúdo. 


\section{Considerações Finais}

Mediante o problema de lecionar para uma turma desafiadora e alcançar uma aprendizagem significativa para esses alunos, surgiu esta dissertação. Tendo o compromisso de seguir a Proposta Curricular do Estado, em suas aulas, percebeu a professora-pesquisadora, a necessidade de aprofundar seus estudos em metodologias de ensino diferenciadas, mais precisamente, as investigações matemáticas.

A partir desse estudo, ocorreu a proposição de uma sequência didática, pensada para uma sala de aula real e desafiadora, a fim de gerar possibilidade concreta de aplicações de atividades investigativas, que levassem em conta os princípios norteadores e conteúdos curriculares da Proposta Curricular.

A aplicação da sequência ocorreu de uma forma agradável, onde todos passaram a ser corresponsáveis pelo processo de ensino e aprendizagem. As atividades, realizadas em grupos, foram norteadas por um contrato didático negociado. Neste, através de uma roda de conversa, combinou-se a participação e atitudes de todos os envolvidos (professora e alunos). A atividade prosseguiu através de etapas ou tarefas, onde mediante investigações, o conhecimento matemático foi sendo construído.

A escolha das atividades investigativas partiu do pressuposto de que estas, ao serem aplicadas aos alunos, desenvolvem os eixos norteadores de competências, presentes na Proposta Curricular do Estado de são Paulo: expressão/compreensão, argumentação/decisão e contextualização/abstração. Mais do que nunca, desenvolvem alunos participativos, críticos, colaborativos, atuantes e autônomos.

As tomadas de decisões, realizadas em grupos, favoreceram a consolidação das relações interpessoais entre os alunos, além de aproximar a professora dos educandos, fortalecendo laços de companheirismo. Isso pôde ser provado em todas as etapas da sequência didática que foram executadas, mais precisamente nas segunda e terceira, como mostrado no capítulo anterior.

Além de favorecer as relações interpessoais, conhecimentos matemáticos investigados e desenvolvidos puderam ser aprendidos de forma significativa, onde não se tinha um 
caminho pronto ou um modelo a ser seguido. Através dos registros e de relatos, pôde-se perceber a busca pelo conhecimento matemático e a integração de todos os membros dos grupos, ora construindo tabelas, gráficos, ou realizando os cálculos de porcentagens. Mesmo alunos mais fracos participaram, mostrando sua evolução nos registros. Eis mais uma vantagem das atividades investigativas em matemática: o desenvolvimento do aluno na sua totalidade, seja da disciplina em específico, interligando conteúdos dentro da própria Matemática, seja na língua materna, ou em suas formas de expressão oral e escrita.

Diferentemente das aulas tradicionais, onde os alunos são dispostos em fileiras, e o professor é o autor do processo, as atividades investigativas favorecem a mobilidade dos alunos, ora em grupos, ora em roda, dentre outras disposições, ora trocando ideias, ora pesquisando nos livros, favorecendo a fixação da atenção sobre as tarefas a serem realizadas e, consequentemente, a aprendizagem. As constantes devolutivas e orientações realizadas pela professora, nos registros, mostrou o benefício desta prática nas aulas, fazendo com que os alunos analisassem os erros e buscassem por novas ações. Isso é a construção do conhecimento!

Sala numerosa, indisciplinada, com defasagem de aprendizagem, sem muitos recursos... Sim, a aprendizagem é possível! E através das atividades investigativas, ela se torna significativa e desenvolve a autonomia, além de beneficiar as relações interpessoais. Uma crítica que pode ser feita a este tipo de abordagem em sala de aula é que ela toma um tempo considerável para trabalhar os conteúdos matemáticos. Por esse motivo, é claro que devemos mesclar outras metodologias de ensino, cada uma com seu benefício. Como decidir? Cabe ao bom professor diagnosticar, avaliar e tomar decisões, a fim de proporcionar a aprendizagem para todos os seus alunos, mesmo que em diferentes tempos e níveis, para cada um. Porém, um suposto "gasto excessivo" de tempo, como mostrou o relato do capítulo anterior, é compensado pelas vantagens que as investigações matemáticas proporcionam, quais sejam: o maior interesse dos alunos pela própria aprendizagem; o desenvolvimento do raciocínio lógico e da argumentação, nas tomadas de decisões; a autonomia para pesquisar, nos livros ou em outras fontes, sobre assuntos ainda pouco conhecidos; a promoção das interligações entre os conhecimentos prévios dos alunos em Matemática e entre os diferentes conteúdos dessa área; o desenvolvimento de habilidades de expressão oral e escrita; a possibilidade de avaliação contínua dos alunos, no acompanhamento dos registros das tarefas; a melhoria das condutas disciplinares em sala de aula. 
É claro que, para que todos esses benefícios possam ser alcançados, o professor deve conhecer bem esta proposta metodológica e apresentar-se como uma peça chave na mediação de todo o processo em sala de aula.

Finalizando, acredita-se que este trabalho, através da propositura, aplicação e do estudo de um caso de ação na prática escolar, caracterizado numa pesquisa-ação, juntamente com as disciplinas cursadas no PROFMAT, proporcionaram a esta professora um grande desenvolvimento, tanto no que diz respeito aos conhecimentos dos conteúdos de Matemática, quanto aos conhecimentos pedagógicos dos conteúdos e de sua inter-relação com o conhecimento sobre os currículos. Como já colocado por Shulman (1986), esta é a base sobre a qual a qualidade do trabalho do professor poderá ser alcançada, quando aliada à suas aprendizagens na prática. E será somente a partir desses conhecimentos que o professor poderá decidir sobre quais, quando, como e por que utilizar metodologias diferenciadas em suas aulas de Matemática. 


\section{Referências}

ANDRÉ, M. E. D. A. Etnografia da Prática Escolar. Campinas: Papirus, 2008.

BROUSSEAU, G. Fondements et méthodes de la didactique dês mathématiques. Recherches em Didactique dês Mathématiques, vol. 7, no. 2, Grenoble, 1986.

IEZZI, G.; DOLCE, O.; MACHADO, A. Matemática e Realidade: 6 ${ }^{\mathbf{a}}$ série. São Paulo: Atual, 2005.

IMENES, L. M.; LELLIS, M. Matemática: Imenes \& Lellis- $7^{0}$ ano. São Paulo: Moderna, 2009.

PINTO, N. B. O Erro como Estratégia Didática. Curitiba: Papirus, 2000.

PONTE, J. P. da; BROCADO, J.; OLIVEIRA, H.M. Investigações Matemáticas na Sala de Aula. Belo Horizonte: Autêntica, 2003.

PONTE, J. P. da. Investigar, Ensinar e Aprender. Actas do ProfMat (CD-ROM, p.25-39). Lisboa: APM, 2003.

SÃO PAULO (Estado), Secretaria da Educação. Caderno do Aluno. Matemática $-7^{\circ}$ ano São Paulo: IMESP, v. 1, 2, 3 e 4, 2008.

SÃO PAUlO (Estado), Secretaria da Educação. Proposta Curricular do Estado de São Paulo. São Paulo, SP, 2008.

SÃO PAULO (Estado), Secretaria da Educação. Relatório Pedagógico de Matemática SARESP 2011. São Paulo, SP, 2012.

SHULMAN, L.S. Those who understand: knowledge growth in teaching. Educational Researcher, Washington, v.15, n.2, p.4-14, 1986. 